by Kumar Batuk Joshi ${ }^{1}$, Nilanjana Sorcar ${ }^{1 *}$, Naresh Chandra Pant ${ }^{2}$, V. Nandakumar ${ }^{1}$, Talat Ahmad ${ }^{2,3}$, and J. K. Tomson ${ }^{1}$

\title{
Characterization of multiple episodes of melt generation from lower crust during Archaean using amphibole composition
}

\author{
${ }^{1}$ ESSO-National Centre for Earth Science Studies, Thiruvananthapuram, Kerala, India; *Corresponding author, E-mail: nilageo83@gmail.com \\ ${ }^{2}$ Department of Geology, University of Delhi, Delhi, India \\ ${ }^{3}$ Vice Chancellors Office, University of Kashmir, Srinagar, India
}

(Received: June 24, 2020; Revised accepted: November 18, 2020)

https://doi.org/10.18814/epiiugs/2020/020096

Spatial association of tonalite trondhjemite granodiorites (TTGs) and high-K granitoids (anatectic and hybrid granites) from the Bundelkhand Craton (BC), Central India, is well known. Geochronological data indicates multiple episodes of formation of these high silica rocks showing a spread of $\sim 1$ Ga during Paleo to Neoarchaean. In the present study, we try to understand the evolution of TTGs and high-K granitoids (hybrid granites) from the BC using amphibole composition. The amphibole in both TTGs and high-K granitoids (hybrid granites) from the BC are characterised as magmatic, zoned, and calcic in nature. We find that the amphibole composition of the studied rocks is dominated by magnesiohornblende along with less common occurrence of tschermakite, magnesiohastingsite and edenite. Overall variation in amphibole compositions in terms of exchange vectors show a well defined linear trend (except for a late stage low-grade metamorphic readjustment), which suggests melt control over crystallization and evolution of amphibole chemistry. Moreover, the geothermobarometric analysis points towards higher pressure formation of TTGs in comparison to that of high-K granitoids (hybrid granites), with nearly the same temperature conditions in both the cases. Combining all our findings, we propose the evolution of the two considered rock types through lower crustal melting under varying $P_{H 2 O}$ conditions at different depths of emplacement.

\section{Introduction}

Archaean cratons represent remnants of old and stable continental crust. They provide a window to understand fundamental geodynamic processes (Windley, 1984; Condie and O'Neill, 2010), for instance, the formation of the earliest continental crust, the onset of plate tectonics, the start of erosion and recycling of material into the mantle, and the emergence of life which brought dramatic changes to the
Earth's surface (Lowe and Tice, 2007; Hawkesworth et al., 2010, 2017; Dhumie et al., 2011, 2015; Rosas and Korenaga, 2018). All the Archaean crustal segments contain large exposures of granitoid lithologies such as sodic tonalite-trondhjemite-granodiorites (TTGs) series and high-K granitoids series (containing both anatectic and hybrid granites) (Condie, 1993; Hölttä et al., 2014; Laurent et al., 2014; Joshi et al., 2017; Singh et al., 2018; Joshi and Slabunov, 2019). These different granitoids either represent nearly contemporaneous emplacement, or an evolution spreading over several hundred million years (Frost et al., 2006). Based on the field and experimental data, the general belief is that the subduction related magmatism is responsible for the continental crust formation during Archaean (Frost et al., 1998; Grove et al., 2003; Lee et al., 2007; Jagoutz et al., 2013). Sodium rich TTGs are the major component of the Archaean crust and are considered to be formed by partial melting of the hydrous basalt, either in a subducting slab or in overthickened mafic crust (Arth and Hanson, 1972; Jahn et al., 1981; Martin, 1994; Hoffman et al., 2011; Nagel et al., 2012). On the other hand, the high-K granitoids (anatectic granites) are typically associated with collisionally thickened crust and are interpreted to be formed by partial melting of the older continental crust (Champion and Sheraton, 1997; Sawyer, 1998; Dey et al., 2012; Mikkola et al., 2012; Hawkesworth et al., 2017). Also, in some cases, a contribution from the mantle is demonstrated for the formation of high-K granitoids (hybrid granites) (Sylvester, 1994; Smithies and Champion, 2000; Moyen et al., 2001; Halla et al., 2009; Joshi et al., 2017; Halla, 2018; Moyen, 2019). However, formation of the Si-rich TTGs and high-K granitoids can be treated either as (i) a result of partial melting of lower crust, or (ii) a water present fractionation of Si-poor cumulates, or (iii) a variable combination of these two end-member processes (Bucholz et al., 2014), and the consideration (ii) possibly represents hydrous arc magma setting. Palin et al. (2016) suggested that Archaean TTGs (low potassic in nature) can be formed by partial melting of hydrated metabasalt; in succession partial melting can be evolved in water under-saturated environment which induces the change in melt chemistry (K enrichment) in due course. Thus, under variable $\mathrm{P}_{\mathrm{H} 2 \mathrm{O}}$ conditions, TTGs and High $\mathrm{K}$ granitoids can be formed in Archaean.

Amphiboles and biotites are commonly present in both TTGs and 
high-K granitoids (Moyen et al., 2003; Martin et al., 2010; Laurent et al., 2014; Joshi et al., 2017). Experimental studies suggest that in comparison to other common hydrous silicate minerals (e.g., biotite), igneous amphiboles are characterised by significant compositional diversity owing to their crystallization from diverse melt /magma composition ranging from basaltic to rhyolitic (Zhang et al., 2017). Amphibole is also sensitive to different condition of oxygen fugacity. Consequently, amphibole chemistry is a suitable archive for retrieving physico-chemical conditions of crystallization of mafic rocks (e.g., Hammarstrom and Zen, 1986; Hollister et al., 1987; Holland and Blundy, 1994; Ridolfi and Renzulli, 2012; Putirka, 2016). Considering this, presence of amphiboles in spatially associated TTGs and Low Silica High Magnesium (LSHM) high-K granitoids (hybrid granites) of the $\mathrm{BC}$, provides an opportunity to utilise amphibole compositions to understand the Archaean magma evolution spread over several hundred million years, and this forms the subject of our present study.

\section{General Geology of the Bundelkhand Craton (BC)}

The Bundelkhand Craton (BC) is a semi-circular granite-greenstone terrane (Fig. 1) lying to the north of Central Indian Tectonic Zone (CITZ) and it has an aerial extent of about $26000 \mathrm{sq} \mathrm{km} \mathrm{(Basu,}$ 1986; Mondal et al., 2002; Singh and Slabunov, 2016; Joshi et al., 2017). It is bounded by Paleoproterozoic (2.0-1.8 Ga) Gwalior (Northwest), Sonrai (South) and Bijawar (Southeast) basins which are overlain by Mesoproterozoic Vindhyan Supergroup that occur at three sides of the craton. The northern side of the $\mathrm{BC}$ is covered by Indo-Gangetic alluvial plains (Fig. 1) (Basu, 1986; Manglik et al., 2015; Nasipuri et al., 2019).

The dominant lithology in BC consists of Neoarchaean potassic granites which are intruded into Paleo-Mesoarchaean TTG gneisses and supracrustal units (Mondal et al., 2002; Singh and Slabunov, 2016;

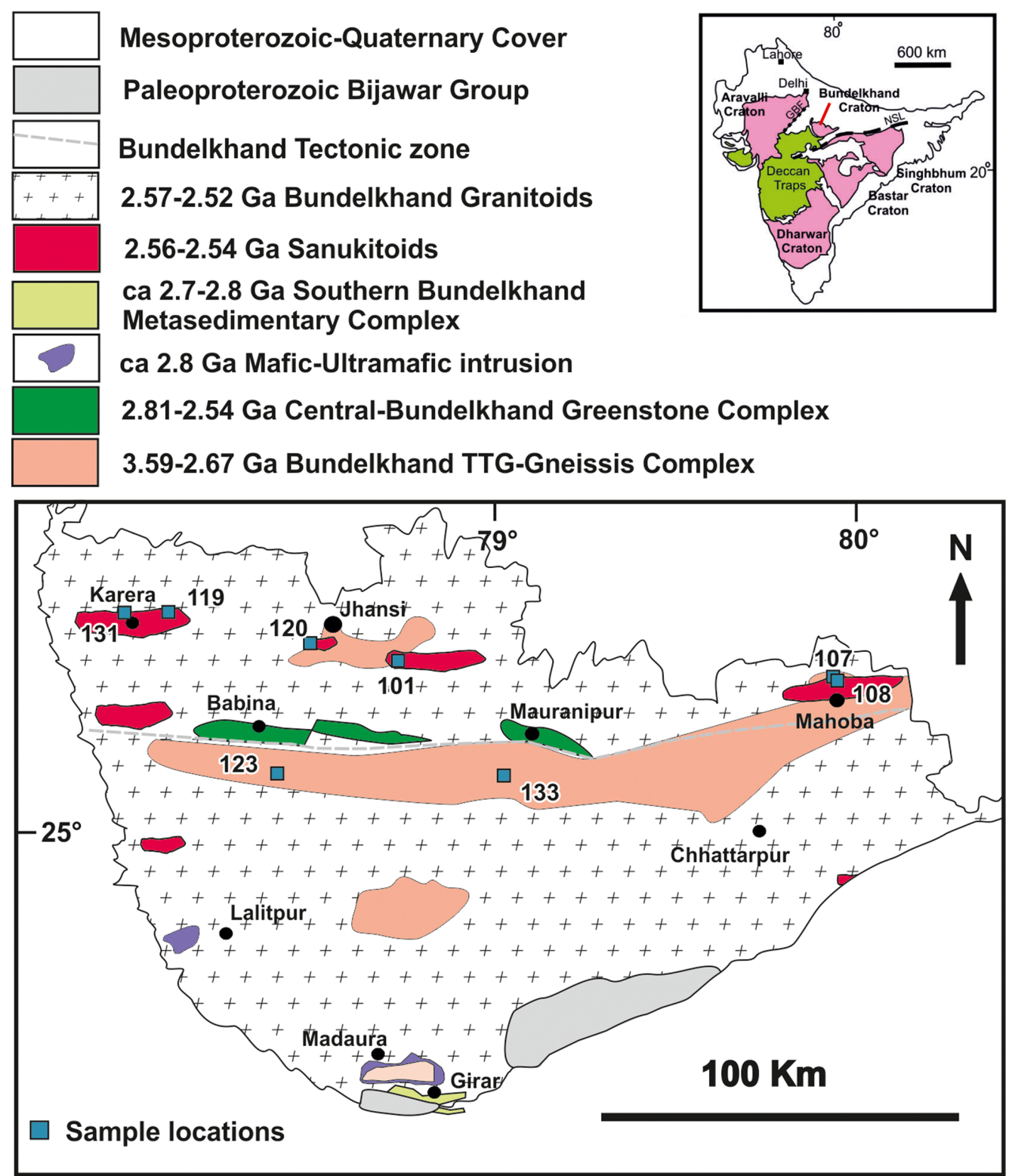

Figure 1. Generalised geological map of the BC (after Basu, 1986; Joshi et al., 2017, Slabunov et al., 2017a; Joshi and Slabunov, 2019). The inset shows an outline map of India showing the different cratons of the Indian Shield (after Radhakrishna 1989). 
Table 1. Representative ages of TTGs and high-K granitoids from Bundelkhand craton, India

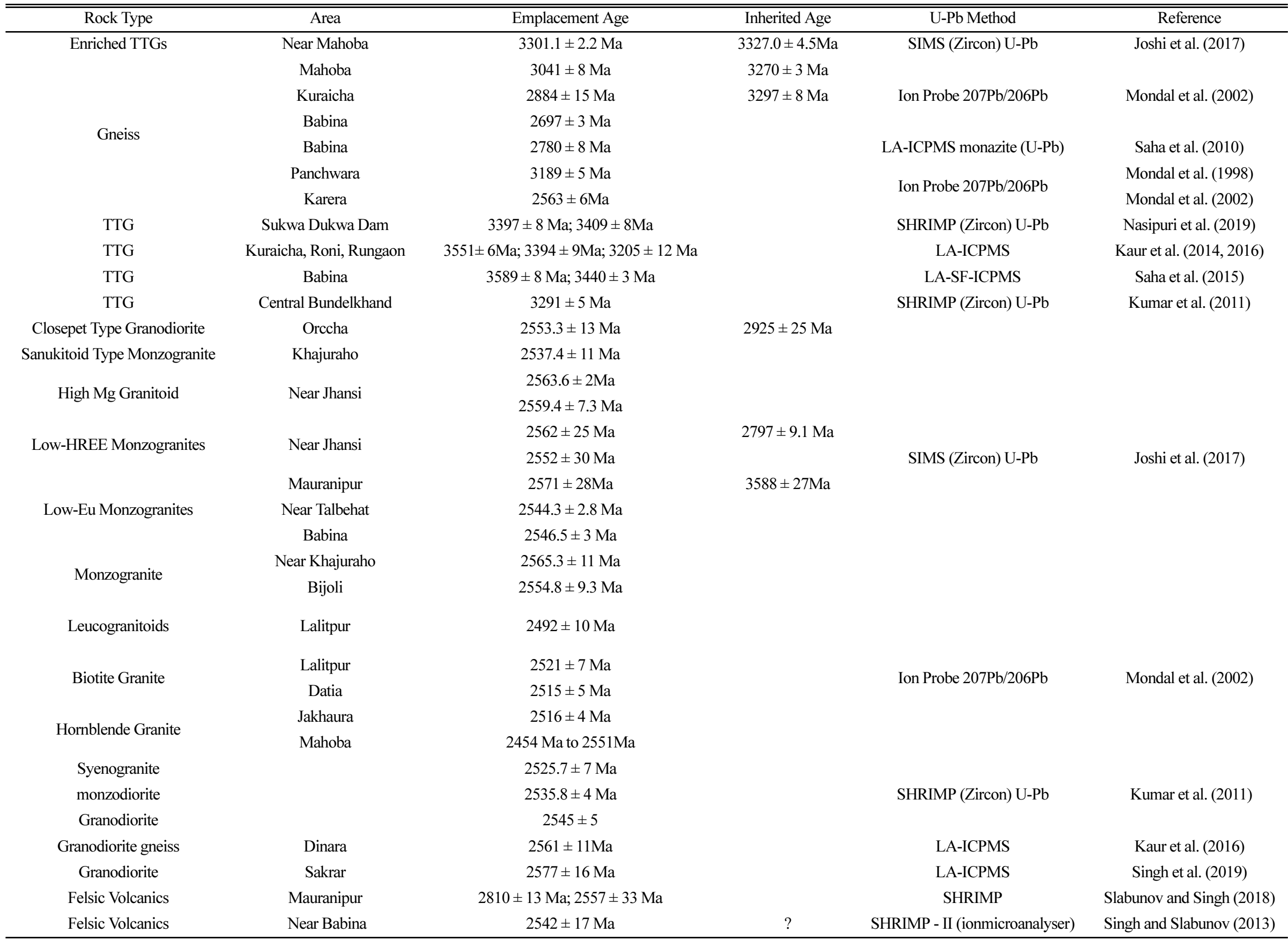


Joshi et al., 2017). Singh and Slabunov (2016) reported two E-W trending Archaean supracrustal complexes in the BC: (i) central Bundelkhand complex extending from Babina to Mauranipur, and (ii) southern Bundelkhand complex extending from Rungaon to Girar. The central Bundelkhand complex consists of various lithologies, like, high magnesian pillow basalt, basaltic komatiite, volcaniclastic metasediments, serpentinised ultramafic rocks, banded iron formation (BIF) with local interlayer of chert and felsic volcanics (dacite and rhyolite) along with garnet chlorite schists, amphibolites, chlorite-actinolite-talc bearing ultramafic schists, and corundum-bearing white schists. On the other hand, southern Bundelkhand complex is dominated by quartzite, BIF, chlorite schist, and marble (Malvia et al., 2006; Singh and Slabunov, 2016; Slabunov et al., 2017a; Slabunov and Singh 2018; Alfimova et al., 2019).

Distinct episodes of TTGs formation viz. $\sim 3.59 \mathrm{Ga}, 3.56 \mathrm{Ga}$ and $\sim 3.44 \mathrm{Ga}$ (near Babina and Mauranipur), 3.3 Ga, 3.2 Ga (near Mahoba, Girar and Rungaon), and $2.75 \mathrm{Ga}$ (Babina) are reported from the Bundelkhand craton (Mondal et al., 2002; Kaur et al., 2014, 2016; Saha et al., 2016; Joshi et al., 2017; Singh et al., 2019; Nasipuri et al., 2019). Joshi et al. (2017) geochemically divided TTGs of the BC into low-HREE and enriched TTGs. They argued that the low-HREE types were formed by low-degree partial melting of basalt or amphibolite, but in-situ melting of amphibolite enclaves formed the enriched varieties. Hf isotopes in zircon from TTGs suggest reworking of older mafic and felsic sources between 3.55 and $3.20 \mathrm{Ga}$ in the craton.

The TTGs and greenstone lithologies are intruded by Neoarchaean high-K (anatectic and hybrid granites) granitoids including sanukitoids (hybrid granites) (Fig. 1; Table 1) (Mondal et al., 2002; Kaur et al., 2016; Verma et al., 2016; Joshi et al., 2017; Singh et al., 2019; Joshi and Slabunov, 2019). Recently, a few studies have addressed the high-K granitoid magmatism (Kaur et al., 2016; Joshi et al., 2017; Singh et al., 2019), and reported its calc-alkaline nature and the origin either in subduction related tectonic setting or subduction-collision related environment (Kaur et al., 2016; Joshi et al., 2017; Singh et al., 2019).

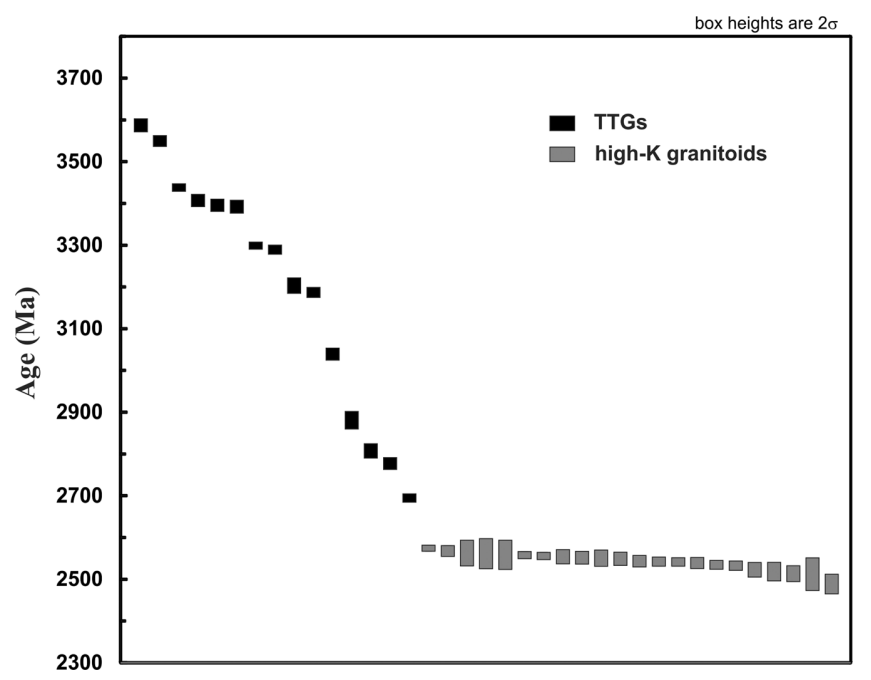

Figure 2. Age distribution for TTGs and LSHM high-K granitoids (including sanukitoids/hybrid granites) analysed from the BC. Data from Mondal et al. (1998, 2002), Saha et al. (2015), Kaur et al. (2014, 2016), Verma et al. (2016), Joshi et al. (2017), Singh et al. (2018), Nasipuri et al. (2019).
Saha et al. (2011) reported Neoarchaean high-P metamorphism in the $\mathrm{BC}$ which supports the idea that plate tectonic processes were operational in the Neoarchaean and the inferred conditions represented subduction-like setting. Joshi et al. (2017), based on major and trace element data, divided high-K granitoids into low silica high magnesium (LSHM; hybrid granites) and high-silica low magnesium (HSLM; anatectic granites) group. On the basis of whole rock chemistry and $\mathrm{Nd}$ isotopes, the former group (LSHM) points to mantle or mixed mantle and crustal sources, and the latter (HSLM) indicate crustal sources (Joshi et al., 2017; Singh et al., 2019). A plot of age vs. TTGs and high-K granitoids (Fig. 2) shows the following features: (i) majority of TTGs are restricted to $>3,100 \mathrm{Ma}$ with a minor exception around ca. 2,700 Ma, and (ii) the high-K granitoids are restricted around ca. 2,500 Ma indicating a time separated origin for the two rock suites.

The above lithologies are traversed by NW strike, NE-SW to ENEWSW strike trending mafic dyke swarms, and NNE-SSW to NE-SW trending giant quartz veins which represent the last magma-related hydrothermal activity in the massif (Basu, 1986; Mondal and Zainuddin, 1997; Pati et al., 1997, 2007; Mondal and Ahmad, 2001; Mondal et al., 2002). The dykes are non-foliated dolerites and cross-cut the TTGs and granites (Pradhan et al., 2012). Based on ${ }^{40} \mathrm{Ar} /{ }^{\beta 9} \mathrm{Ar}$ and U-Pb zircon geochronology, Rao et al. (2005) and Pradhan et al. (2012) suggested that two phases of mafic magmatic events occurred in the Bundelkhand Craton. First, NW-SE trending dykes formed ca. 2.0 Ga, and then NE-SW oriented dykes formed at approximately $1.10 \mathrm{Ga}$. The giant quartz veins were probably emplaced owing to ongoing crustal movements subsequent to the stabilization of the cratonic segment at about $2.5 \mathrm{Ga}$. Again, some authors have interpreted these two features of dykes (mafic magmatism) to be a result of tectonically controlled hydrothermal activity along vertical to subvertical shear zones that formed in response to extensional tectonics at 1.9-1.8 Ga (Pati et al., 2007; Slabunov et al., 2017b).

\section{Field Setting and Petrography}

The TTGs are exposed in the eastern part of the BC near Mahoba, in Mauraniupur and Babina, which typically show gneissic banding with alternating layers of leucocratic and malenocratic bands. Around Mahoba, TTGs occur as deformed and migmatised hillocks (Fig. 3a-d). In eastern $\mathrm{BC}$ these are present as deformed coarse-grained heterogeneous bodies and are traversed by relatively undeformed high-K (potassic) granitoids and pegmatites (Fig. 3c). In Mauranipur, the TTGs are present as low-lying outcrops and range from homogeneous to heterogeneous bodies occasionally containing porphyric feldspar crystals. Migmatised nature is evident from the alternate layers of leucosomes and malenosomes in some outcrops (Fig. 3e). TTGs near Babina occur as scattered outcrops, migmatised, and intruded by porphyritic high-K granitoids (Fig. 3f-g). The grey to dark grey colored high-K granitoids are exposed in Mahoba, Jhansi, and Karera (Fig. 3 h-j). These are fine to mediumgrained rocks having feldspar phenocrysts. In Mahoba, these dark colored high-K granitoids intrude the TTGs (Fig. 3a) and are often intruded by porphyritic high-K granitoids (Fig. 3h) and pegmatites (Fig. 3a). At places the grey to dark grey colored high-K granitoids show signs of deformation like the elongation of feldspar phenocryst and the presence of schlieren, imparting gneissic appearance to these rocks (Fig. 3i-j). 

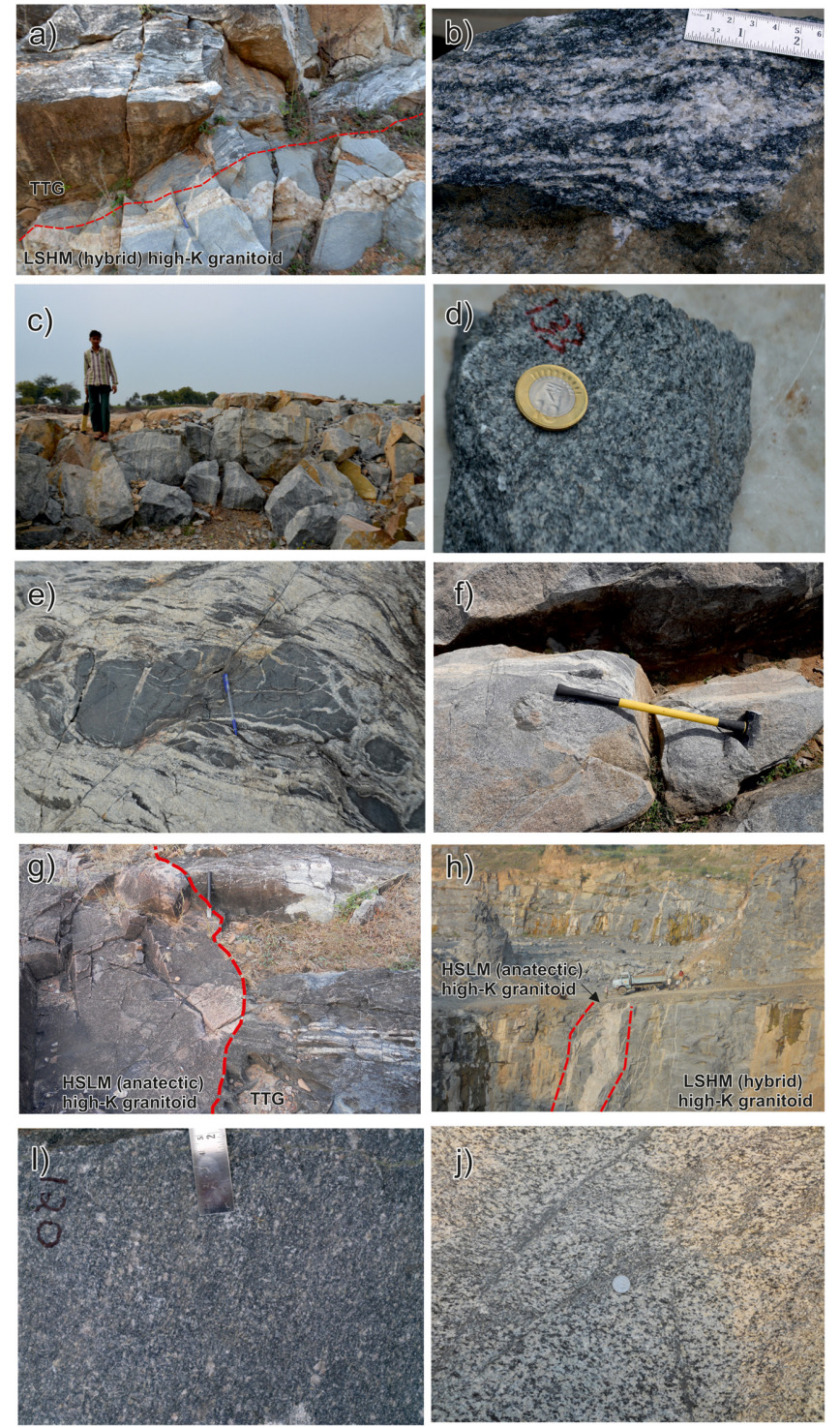

Figure 3. a) Contact between migmatised TTG ( 3.3 Ga) BETTG 107 and LSHM (hybrid) high-K granitoid (BSTG 108) near Mahoba (from Jayananda et al., 2020); b) Hand specimen of migmatised TTG (BETTG 107) from Mahoba; c) Localised melting producing leucosomes and malenosomes near Mauranipur; d) Hand specimen of migmatised TTG from Mauranipur; e-f) Leucosome and malenosomes in TTGs near Mauranipur and Babina; g) HSLM (anatectic granite) high-K granitoid intruding TTGs near Babina; h) HSLM (anatectic granite) high-K granitoid intruding LSHM (hybrid) high-K granitoid near Orccha; i-j) Slightly deformed LSHM (hybrid) high-K granitoids from Orcha. Sample locations and their descriptions are presented in Table 2.

Sample locations of the studied granitoid varieties and their descriptions are given in Table 2.

The TTGs are inequigranular and consist of coarse-grained plagioclase, quartz, K-feldspar, biotite, and amphibole. Estimates of modal abundance of the phases from the study of representative TTGs indicate a dominance of plagioclase ( $\sim 45 \mathrm{vol} \%)$, along with quartz ( $\sim 22 \mathrm{vol} \%)$, K-feldspar ( $\sim 18$ vol\%), biotite ( $\sim 10 \mathrm{vol} \%$ ), and amphibole ( $\sim 5 \mathrm{vol} \%)$. Accessory phases ( $\sim 1$ vol\%) include titanite, epidote, apatite, and zircon.

Plagioclase occurs as medium to large anhedral to subhedral grains
(Fig. 4a, b). At places plagioclase is partly altered to sericite in the core, while the rims remain unaffected (Fig. 4a), this suggests more than one crystallisation event separated by hydrothermal alteration. $\mathrm{K}$-feldspar is present as coarse xenomorphic grains, locally perthitic; the lamellae are mostly lenticular (flame perthite). Few of the felsic minerals are deformed: marked by the presence of sutured grain boundaries, fine-grained recrystallised quartz and feldspar in the matrix, and along the grain boundaries of coarser quartz and feldspar (Fig. 4b). It is corroborated by the occurrence of undulose extinction in major minerals. Texturally, two modes of biotite (biotite I and II) are identified. Biotite-I is prismatic, coarse-grained, and occur as well-developed crystals in the interstitial spaces as well as inclusions in feldspar. Locally these are oriented and are concentrated within the melanocratic layers defining foliation (Fig. 4c). Foliation is wavy and locally shows an anastomosing pattern forming dark selvedges which border the leucocratic layer. Sporadic replacement of biotite by chlorite is also evident from the studied TTGs samples. Biotite-II is present either as randomly oriented small flakes within the quartzo-feldspathic zone or is present around the large amphibole crystals (Fig. 4f). Locally TTGs show gneissic texture which is defined by alternate compositional banding of the mafic and felsic minerals (Fig. 4c). Felsic minerals comprise quartz, plagioclase and $\mathrm{K}$-feldspar, while biotite is the major mafic mineral followed by amphiboles. Amphiboles are medium to coarsegrained and subhedral. Large amphiboles are commonly present in interlocking texture with plagioclase, K-feldspar and quartz in the groundmass and are not aligned. The interlocking texture, as well as the straight grain boundaries between amphibole and plagioclase or K-feldspar (Fig. 4d,e), indicates magmatic nature of the amphiboles in the TTGs. Contacts between amphibole and plagioclase are locally corrugated, and at places amphiboles are replaced by small biotite laths (biotite-II) (Fig. 4f); all such textural features suggest a marginal influence of late-stage subsolidus/metamorphic effects on the TTGs.

The high-K granitoids was previously studied in the craton and based on geochemistry have been divided into LSHM and HSLM. The LSHM are amphibole bearing while the HSLM has low amphibole content (Joshi et al., 2017), therefore, the HSLM varieties have not been considered for discussion in this contribution. The LSHM (hybrid granites) high-K granitoids are characterised by the dominance of Kfeldspar over plagioclase in comparison to the TTGs. Mineral abundances depict higher amount of quartz and K-feldspar with average modal content of quartz ( $\sim 3 \mathrm{vol} \%$ ), K-feldspar ( $\sim 35 \mathrm{vol} \%)$, plagioclase $(\sim 15 \mathrm{vol} \%)$, amphibole $(\sim 15 \mathrm{vol} \%)$ and biotite $(\sim 7 \mathrm{vol} \%)$ showing variation from TTG's. The common accessory minerals ( 1 vol\%) are zircon, titanite, epidote and apatite. These rocks show weak gneissic layering of biotite alternating with $\mathrm{K}$-feldspar, quartz and plagioclase. The proportion of K-feldspar and amphibole in LSHM is higher compared to the TTGs. Plagioclase and K-feldspar occur as subhedral to anhedral grains of varying sizes. K-feldspar is perthitic; the lamellae are either lenticular (flame perthite) (Fig. 4g) or patchy (Fig. 4h). Cores of the K-feldspar grains are commonly sericitised and are surrounded by the growth of plagioclase (Fig. 4i) suggesting more than one generation of magmatic activity. Quartz is coarse to fine-grained. Fine-grained microcrystalline quartz is present along grain boundaries of felsic minerals while the coarser fractions are associated with matrix minerals. Amphiboles are present in two textural modes: amphibole-I and amphibole-II. Amphibole-I is present as coarse to medium grains in associa- 
Table 2. Sample locations with description of TTGs and LSHM (hybrid) high-K granitoids from Bundelkhand Craton

\begin{tabular}{|c|c|c|c|c|c|c|c|}
\hline Rock Type & Area & Sample Number & Loca & ation & Field Description & Minerals & Age \\
\hline \multicolumn{8}{|l|}{ TTGs } \\
\hline Enriched TTGs & Mahoba (Karara) & BETTG 107 & N 2519'49.3" & E 7949'04.0" & $\begin{array}{l}\text { Migmatised TTGs intruded by LSHM } \\
\text { granodiorites and pegmatites }\end{array}$ & \multirow{3}{*}{$\begin{array}{l}\text { Pl ( } \sim 45 \text { vol\%), Qtz }(\sim 22 \text { vol\%), } \\
\text { Kfs }(\sim 18 \text { vol\%), Bt }(\sim 10 \text { vol\%) } \\
\text { and Hbl }(\sim 5 \text { vol\%) with Acces- } \\
\text { sory phases like titanite, epidote, } \\
\text { apatite, and zircon }(\sim 1 \text { vol } \%)\end{array}$} & $\begin{array}{c}\sim 3.33 \mathrm{Ga} \\
\text { (Joshi et al., 2017) }\end{array}$ \\
\hline TTGs & Babina & BTTG 123 & N $25^{\circ} 11^{\prime} 40.8^{\prime \prime}$ & E $78^{\circ} 28^{\prime} 40.6^{\prime \prime}$ & $\begin{array}{l}\text { Migmatised TTGs intruded by } \\
\text { porphyritic granites (ca. } 2.5 \mathrm{Ga} \text { ) }\end{array}$ & & $\begin{array}{c}\sim 2.69 \mathrm{Ga} \\
\text { (Verma et al., 2016) }\end{array}$ \\
\hline Enriched TTGs & Mauranipur & BETTG 133 & N $25^{\circ} 13^{\prime} 17.28^{\prime \prime}$ & E $79^{\circ} 05^{\prime} 56.55^{\prime \prime}$ & $\begin{array}{l}\text { Slight to moderately migmatised TTGs, } \\
\text { localised melting is evident by the pres- } \\
\text { ence of leusosomes and malenosomes. }\end{array}$ & & $\begin{array}{c}\sim 3.55 \mathrm{Ga} \\
\text { (Kaur et al., 2014) }\end{array}$ \\
\hline \multicolumn{8}{|l|}{ High-K CA granitoids } \\
\hline \multicolumn{8}{|l|}{ LSHM } \\
\hline Sanukitoid granodiorite & Jarguan Abbal & BSTG 119 & N 2527'46.4" & E $78^{\circ} 15^{\prime} 27.6^{\prime \prime}$ & $\begin{array}{l}\text { Homogeneous intrusions, } \\
\text { cut by pegmatite veins }\end{array}$ & \multirow{5}{*}{$\begin{array}{l}\text { Kfs ( } \sim 35 \text { vol\%), Qtz ( } \sim 3 \text { vol\%), } \\
\text { Pl }(\sim 15 \text { vol\%), Hbl }(\sim 15 \text { vol\%) } \\
\text { and Bt }(\sim 7 \text { vol\%) with accessory } \\
\text { phases like titanite, epidote, apa- } \\
\text { tite, and zircon }(\sim 1 \text { vol } \%)\end{array}$} & $\begin{array}{c}\sim 2.56 \mathrm{Ga} \\
\text { (Joshi et al., 2017) }\end{array}$ \\
\hline Sanukitoid granodiorite & Karera Fort & BSTG 131 & N $25^{\circ} 27^{\prime} 33.68^{\prime \prime}$ & E $78^{\circ} 08^{\prime} 40.89^{\prime \prime}$ & $\begin{array}{l}\text { Slightly deformed ourcrop evident by the } \\
\text { presence of augen shaped feldspar grains } \\
\text { giving a faint gneissic appearance }\end{array}$ & & $\begin{array}{l}\sim 2.58 \text { (unpublished ages } \\
\text { (Joshi et al. in preparation) }\end{array}$ \\
\hline Sanukitoid granodiorite & Mahoba (Karara) & BSTG 108 & N 2519'49.3" & E 7949'04.0" & $\begin{array}{l}\text { Undeformed granodiorites cutting } \\
\text { across TTGs }(\mathrm{Ca} .3 .3 \mathrm{Ga})\end{array}$ & & $\begin{array}{l}2.57 \text { (unpublished ages; } \\
\text { Joshi et al. in preparation) }\end{array}$ \\
\hline Sanukitoid granodiorite & near Raksa & BSTG 120 & N 2527'3.2" & E 78²9'27.7" & $\begin{array}{l}\text { Deformed ourcrop evident by the pres- } \\
\text { ence of augen shaped feldspar grains } \\
\text { giving a faint gneissic appearance }\end{array}$ & & $\begin{array}{c}\sim 2.55 \mathrm{Ga} \\
\text { (Joshi et al., 2017) }\end{array}$ \\
\hline Closepet-type granodiorite & Orccha & BCTG 129 & N $25^{\circ} 25^{\prime} 05.5^{\prime \prime}$ & E 78³9'05.8" & $\begin{array}{l}\text { Slightly deformed outcrop with } \\
\text { occassional presence of schelerin. }\end{array}$ & & $\begin{array}{c}\sim 2.56 \mathrm{Ga} \\
\text { (Joshi et al., 2017) }\end{array}$ \\
\hline
\end{tabular}


TTGs (a - f)
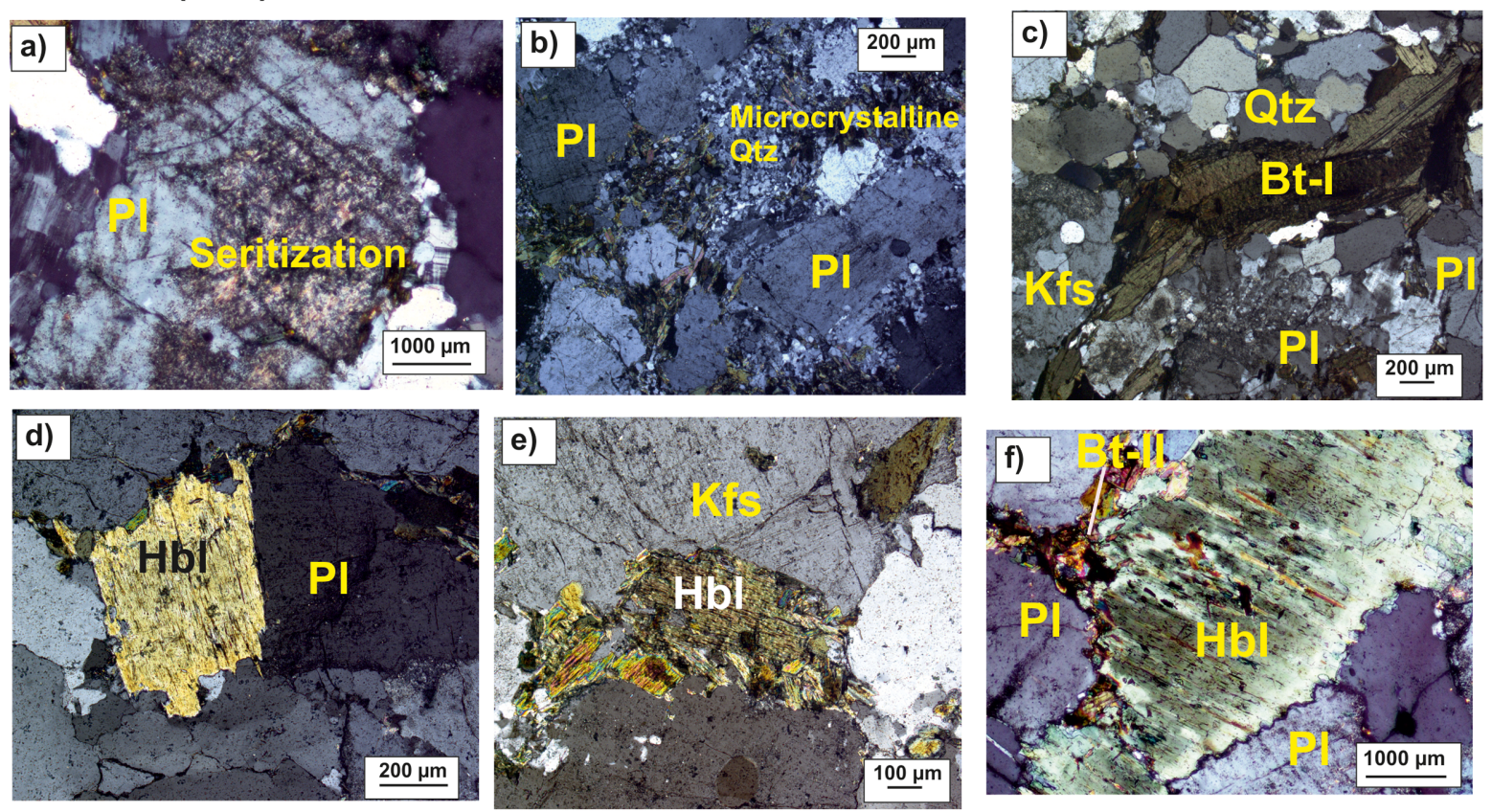

\section{high-K granitoids ( $\mathrm{g}-\mathrm{I})$}
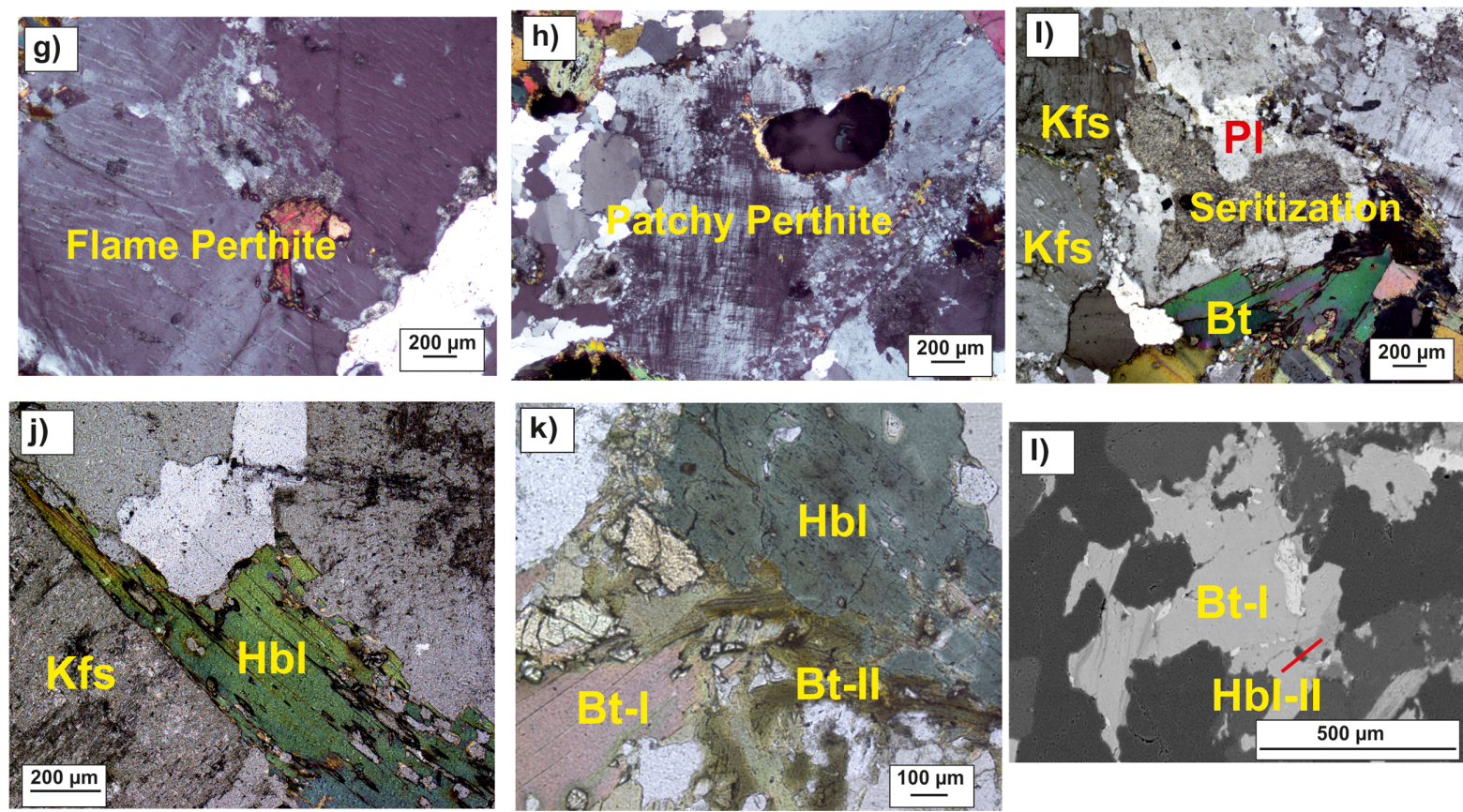

Figure 4. Photomicrographs and BSE images of TTGs (a-f) and LSHM high-K grantoids (hybrid granites) (g-l): (a): Seritization of matrix plagioclase; (b): Development of microcrystalline quartz surrounding plagioclase crystal; (c): Biotite-I defining wavy foliation; (d): Straight grain boundary contact between $\mathrm{Hbl}$ and Pl; (e): Straight grain boundary contact between Hbl and Kfs; (f): Corrugated grain boundary between Pl and $\mathrm{Hbl}$ which are replaced by small biotite laths (biotite-II); (g): Flame perthite; (h) Patchy perthite; (i): Cores of the K-feldspar grains showing sericitization surrounded by the growth of plagioclase; (j): Straight grain boundary contact between Hbl and Kfs; (k): Amphibole-I replaced by small biotite laths; (I): Amphibole-II replacing the large biotite. Mineral abbreviations: Ap - Apatite, Bt - Biotite, Chl Chlorite, Hbl Hornblende, Kfs - K-feldspar, Plg - Plagioclase, Qtz-Quartz, Sp-Sphene, Mag-Magnetite, Zir-Zircon, Ilm - Ilmenite.

tion with opaque, titanite and apatite. The straight grain boundaries between amphibole-I and perthitic K-feldspar (Fig. 4j) also reflect the magmatic nature of the rocks. Amphibole-I is commonly replaced by small biotite laths (Fig. 4k). Amphibole-II occurs rarely as fine-grained varieties which replaces the large biotite grains (Fig. 4i); such textural feature points towards late-stage low-grade metamorphism of the studied rocks. Similar to TTGs, two modes of biotite are identified, i.e., i) biotite-I and ii) biotite-II in this rock. Biotite-I occurs as coarse to medium grained laths forming wavy bands enveloping coarser amphibole crystals. Locally biotite-II, present as small to medium-sized laths, replaces 
amphibole and is associated with titanite and epidote.

In the present study, the mineral abbreviations are adopted from Kretz (1983).

\section{Mineral Chemistry}

Electron microprobe analyses (EPMA) on polished sections was carried out at the Indian Institute of Technology (IIT), Kharagpur using CAMECA SX-100. The operating conditions of the instrument were $15 \mathrm{kV}$ accelerating voltage, $15 \mathrm{nA}$ beam current, and 1-2 $\mu \mathrm{m}$ beam diameter (see Sorcar et al., 2020). Feldspar, biotite and amphibole analyses are obtained from all the granitoid (TTGs, high-K granitoids (hybrid granites)) types. Representative electron microprobe analyses for K-feldspar, plagioclase, biotite and amphibole are given in Table 3a,b and detailed analyses are given in Supplementary Tables S1, S2, S3 and S4 respectively.

\section{Feldspar}

Two primary feldspars are present in TTGs as well as LSHM (hybrid granites) high-K granitoids from the BC: (i) potassic alkali feldspar and (ii) sodic plagioclase. Plagioclase (Table 3a; S-1) from both of granitoids show high $\mathrm{Na}_{2} \mathrm{O}$ content (8.17-11.98 wt.\%), and wide range of $\mathrm{CaO}$ content $(0.25-6.31 \%)$, indicating variable content of anorthite $\left(\mathrm{An}_{1}\right.$ to $\left.\mathrm{An}_{31}\right)$ in conformity with multiple magmatic pulses. The An-Ab-Or diagram (Fig. 5) after Smith and Brown (1988) illustrates that plagioclase in TTGs and LSHM (hybrid granites) high-K granitoids is mostly oligoclase with the occasional presence of some albite and andesine compositions. The plagioclase composition ranges from $A b_{98} A n_{1}$ to $A b_{70} A n_{30}$. Potash feldspar in all the studied granitoid types is rich in nearly pure orthoclase content with very low An and Ab contents (Fig. 5; Table 3a and S-2).

\section{Biotite}

Texturally distinct, type I and II, biotite in TTGs and LSHM (hybrid granites) high-K granitoids are compositionally more or less similar. Biotite from TTGs is mostly Fe rich and has higher Ti compared to those in the LSHM (hybrid granites) high-K granitoids. In TTGs $\mathrm{X}_{\mathrm{FeAvg}}=$ 0.57 whereas $X_{\mathrm{FeAvg}}=0.47$ in LSHM (Table 3a; S-3). Average Ti content of biotite in TTGs and LSHM (hybrid granites) is 0.16 and $0.11 \mathrm{wt} \%$ respectively. Biotite falls in two clusters, viz., Mg-biotite and Fe-biotite, in the $\mathrm{Mg}-\left(\mathrm{Al}^{\mathrm{VI}}+\mathrm{Fe}^{3+}+\mathrm{Ti}\right)-\left(\mathrm{Fe}^{2+}+\mathrm{Mn}\right)$ ternary diagram (Fig. 6a); the plot shows that biotite in Paleoarchaean TTGs and Neoarchaean LSHM (hybrid) high-K granitoids are Mg-rich, whereas Neoarchaean TTGs are rich in Fe. Again, in $\mathrm{FeO}$ vs $\mathrm{MgO}$ plot of biotite (Fig. 6b), a negative trend is observed with clear evidence of enriched $\mathrm{FeO}$ and depleted $\mathrm{MgO}$

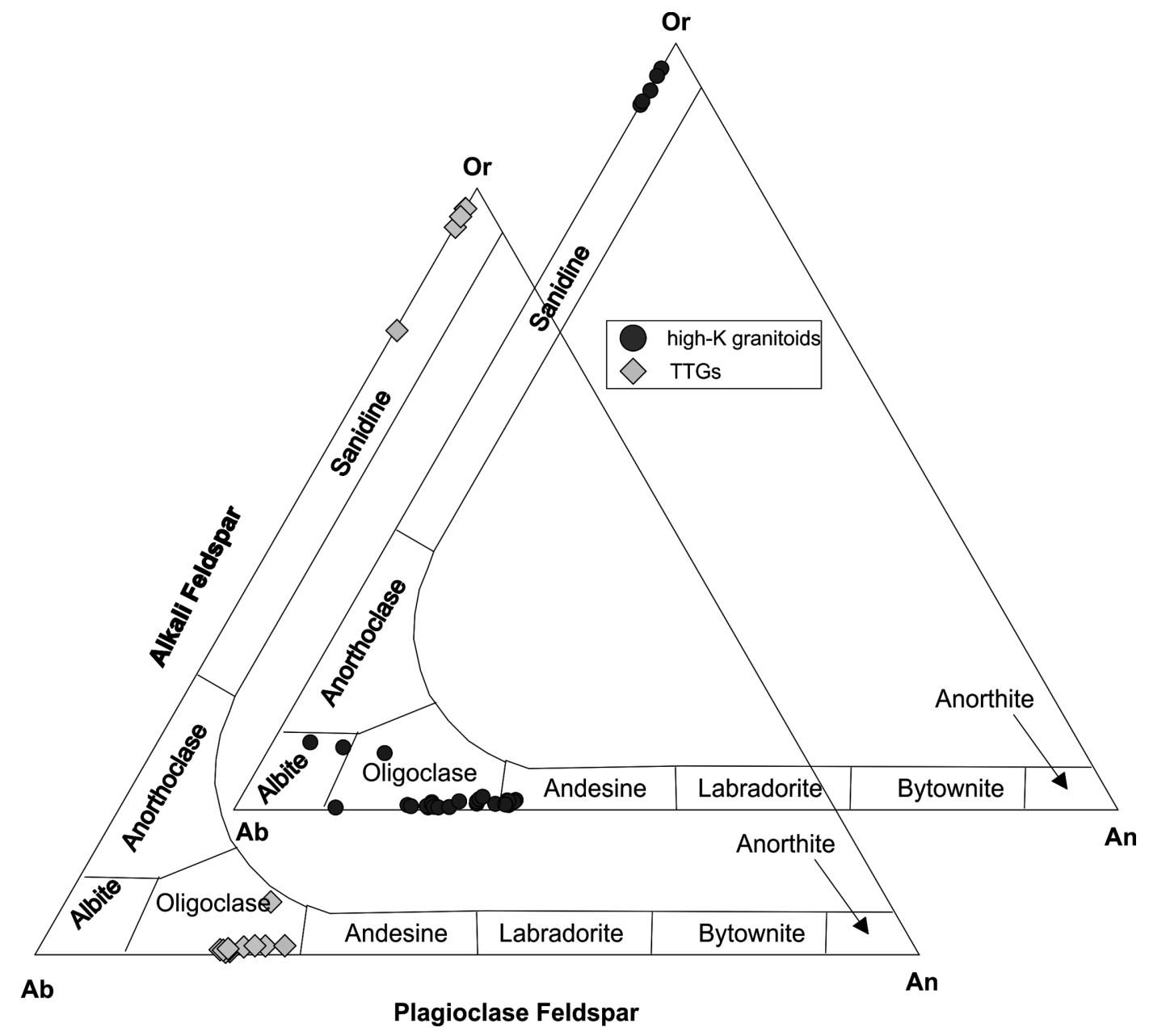

Figure 5. Feldspars chemistry of Bundelkhand Granitoids in the Or-Ab-An diagram (Smith and Brown, 1988). 
contents in Neoarchaen TTGs as compared to Paleoarchaean TTGs.

\section{Amphibole}

Majority of the analysed amphiboles from TTGs belong to the group of calcium amphiboles $\left(\mathrm{Ca}_{\mathrm{B}}>1.5\right)$ with a few affinities to sodic-calcic $\left(\mathrm{Ca}_{\mathrm{B}}<1.5\right)$ varieties (Leake et al., 1997, 2004; Table 3b; S-4). Most of the calcium amphiboles in TTGs and LSHM (hybrid granites) high-K granitoids have $(\mathrm{Na}+\mathrm{K})_{\mathrm{A}}<0.5$ and $\mathrm{Ca}_{\mathrm{A}}<0.5$ and can be classified as magnesiohornblende and less commonly as tschermakite (Fig. 7a). A few amphibole compositions from LSHM (hybrid granites) high-K granitoids plot close to the actinolite field (Fig. 7a) and these compositions generally lie close to the rims of the grains. Very few of the analysed points from TTGs fall in magnesiohastingsite) and edenite $\left((\mathrm{Na}+\mathrm{K})_{\mathrm{A}} \geq 0.5 ; \mathrm{Ti}<0.5\right)$ whereas two measurements from LSHM amphiboles fall in edenite field (Fig. 7b). Some of the analysed amphiboles from both TTGs as well as LSHM (hybrid granites) high-K granitoids (Fig. 7c) plot as magnesiokataphorite and magnesiotaramite with $(\mathrm{Na}+\mathrm{K})_{\mathrm{A}} \geq 0.5,(\mathrm{Ca}+\mathrm{Na})_{\mathrm{B}} \geq$ 1.00 and $0.50<\mathrm{Na}_{\mathrm{B}}<1.50$ (Leake et al.,1997, 2004).

Chemical zoning in amphiboles from both TTGs as well as LSHM (hybrid granites) high-K granitoids can be inferred from the BSE images and X-ray elemental maps (Fig. 8a-i) as well as from the elemental rim to rim line profile plots (Fig. 9-12). Two amphibole profiles each from TTGs and LSHM (hybrid) high-K granitoids are analysed. The results show that the amphiboles from both the granitoid types exhibit well developed $\mathrm{Si}, \mathrm{Mg}, \mathrm{Fe}, \mathrm{Ti}, \mathrm{Na}, \mathrm{Ca}, \mathrm{Al}_{\mathrm{T}}$ zoning. Concentrations of $\mathrm{Na}, \mathrm{Al}_{\mathrm{T}}, \mathrm{Ti}, \mathrm{X}_{\mathrm{Fe}}$ and $\mathrm{Si}$ in amphiboles from TTGs plotted from rim to rim (Fig. 8b-e; Fig. 9-10) show slight increase upto the core where it becomes uneven and finally depletes on the other edge of the grain. On the other hand, $\mathrm{X}_{\mathrm{Mg}}$ shows slight depletion till the core where the concentration is uneven and finally gets enriched at the other end (Fig. 9-10). But Ca contents are relatively constant all through the grain

Table 3a. Representative chemical composition of minerals in the samples of the TTGs and high-K granitoids (hybrid granites)

\begin{tabular}{|c|c|c|c|c|c|c|c|c|c|c|c|c|}
\hline \multirow{3}{*}{$\begin{array}{l}\text { Rock type } \\
\text { Comment }\end{array}$} & \multicolumn{2}{|c|}{ TTGs } & \multicolumn{2}{|c|}{$\begin{array}{l}\text { high-K granitoids } \\
\text { (hybrid granites) }\end{array}$} & \multicolumn{2}{|c|}{ TTGs } & \multicolumn{2}{|c|}{$\begin{array}{c}\text { high-K granitoids } \\
\text { (hybrid granites) }\end{array}$} & \multicolumn{2}{|c|}{ TTGs } & \multicolumn{2}{|c|}{$\begin{array}{l}\text { high-K granitoids } \\
\text { (hybrid granites) }\end{array}$} \\
\hline & & & & & & & & & \multicolumn{2}{|c|}{ Paleoarchean Neoarchean } & & \\
\hline & Kfs & Kfs & Kfs & Kfs & $\mathrm{Pl} *$ & $\mathrm{Pl} *$ & $\mathrm{Pl} *$ & $\mathrm{Pl} *$ & $\mathrm{Bt}$ & $\mathrm{Bt}$ & $\mathrm{Bt}$ & $\mathrm{Bt}$ \\
\hline $\mathrm{SiO}_{2}$ & 67.42 & 65.36 & 64.02 & 64.00 & 62.52 & 62.48 & 61.21 & 61.70 & 36.04 & 34.07 & 37.66 & 38.08 \\
\hline $\mathrm{TiO}_{2}$ & 0.00 & 0.03 & 0.01 & 0.00 & 0.00 & 0.00 & 0.00 & 0.00 & 2.03 & 2.36 & 1.52 & 1.86 \\
\hline $\mathrm{Al}_{2} \mathrm{O}_{3}$ & 18.42 & 18.64 & 18.07 & 18.05 & 22.70 & 22.76 & 23.69 & 23.73 & 15.08 & 15.69 & 14.03 & 14.27 \\
\hline $\mathrm{Cr}_{2} \mathrm{O}_{3}$ & 0.00 & 0.00 & 0.00 & 0.00 & 0.04 & 0.02 & 0.00 & 0.00 & 0.09 & 0.03 & 0.08 & 0.16 \\
\hline $\mathrm{FeO}$ & 0.02 & 0.01 & 0.03 & 0.16 & 0.00 & 0.00 & 0.25 & 0.29 & 20.67 & 26.47 & 19.70 & 20.09 \\
\hline $\mathrm{MnO}$ & 0.00 & 0.01 & 0.00 & 0.08 & 0.05 & 0.06 & 0.00 & 0.00 & 0.54 & 0.40 & 0.29 & 0.42 \\
\hline $\mathrm{MgO}$ & 0.02 & 0.00 & 0.00 & 0.01 & 0.00 & 0.00 & 0.02 & 0.00 & 12.36 & 6.99 & 14.51 & 14.12 \\
\hline $\mathrm{CaO}$ & 0.02 & 0.00 & 0.00 & 0.00 & 4.88 & 4.71 & 5.74 & 5.75 & 0.02 & 0.02 & 0.02 & 0.01 \\
\hline $\mathrm{Na}_{2} \mathrm{O}$ & 0.42 & 0.28 & 0.44 & 0.38 & 9.59 & 9.35 & 8.45 & 8.49 & 0.16 & 0.08 & 0.16 & 0.13 \\
\hline $\mathrm{K}_{2} \mathrm{O}$ & 12.08 & 15.63 & 15.03 & 15.35 & 0.08 & 0.12 & 0.15 & 0.20 & 8.99 & 8.61 & 9.22 & 9.33 \\
\hline Total & 98.88 & 100.19 & 97.60 & 98.05 & 99.85 & 99.49 & 99.51 & 100.16 & 95.97 & 94.72 & 97.18 & 98.46 \\
\hline $\mathrm{O}$ basis & 8.00 & 8.00 & 8.00 & 8.00 & 8.00 & 8.00 & 8.00 & 8.00 & 11.00 & 11.00 & 11.00 & 11.00 \\
\hline $\mathrm{Si}$ & 3.07 & 3.01 & 3.01 & 3.01 & 2.78 & 2.79 & 2.74 & 2.74 & 2.75 & 2.72 & 2.82 & 2.82 \\
\hline $\mathrm{Ti}$ & 0.00 & 0.00 & 0.00 & 0.00 & 0.00 & 0.00 & 0.00 & 0.00 & 0.12 & 0.14 & 0.09 & 0.10 \\
\hline $\mathrm{Al}$ & 0.99 & 1.01 & 1.00 & 1.00 & 1.19 & 1.20 & 1.25 & 1.24 & 1.36 & 1.48 & 1.24 & 1.24 \\
\hline $\mathrm{Al}^{\mathrm{iv}}$ & n.a. & n.a. & n.a. & n.a. & n.a. & n.a. & n.a. & n.a. & 1.25 & 1.28 & 1.18 & 1.18 \\
\hline $\mathrm{Al}^{\mathrm{vi}}$ & n.a. & n.a. & n.a. & n.a. & n.a. & n.a. & n.a. & n.a. & 0.11 & 0.19 & 0.06 & 0.06 \\
\hline $\mathrm{Cr}$ & 0.00 & 0.00 & 0.00 & 0.00 & 0.00 & 0.00 & 0.00 & 0.00 & 0.01 & 0.00 & 0.00 & 0.01 \\
\hline $\mathrm{Fe}$ & 0.00 & 0.00 & 0.00 & 0.01 & 0.00 & 0.00 & 0.01 & 0.01 & 1.32 & 1.77 & 1.23 & 1.24 \\
\hline $\mathrm{Mn}$ & 0.00 & 0.00 & 0.00 & 0.00 & 0.00 & 0.00 & 0.00 & 0.00 & 0.04 & 0.03 & 0.02 & 0.03 \\
\hline $\mathrm{Mg}$ & 0.00 & 0.00 & 0.00 & 0.00 & 0.00 & 0.00 & 0.00 & 0.00 & 1.41 & 0.83 & 1.62 & 1.56 \\
\hline $\mathrm{Ca}$ & 0.00 & 0.00 & 0.00 & 0.00 & 0.23 & 0.22 & 0.27 & 0.27 & 0.00 & 0.00 & 0.00 & 0.00 \\
\hline $\mathrm{Na}$ & 0.04 & 0.03 & 0.04 & 0.03 & 0.83 & 0.81 & 0.73 & 0.73 & 0.02 & 0.01 & 0.02 & 0.02 \\
\hline $\mathrm{K}$ & 0.70 & 0.92 & 0.90 & 0.92 & 0.00 & 0.01 & 0.01 & 0.01 & 0.88 & 0.88 & 0.88 & 0.88 \\
\hline Total & 4.80 & 4.96 & 4.96 & 4.97 & 5.04 & 5.02 & 5.01 & 5.01 & 7.90 & 7.85 & 7.92 & 7.90 \\
\hline $\mathrm{X}_{\mathrm{Ca}}$ & 0.00 & 0.00 & 0.00 & 0.00 & 0.22 & 0.22 & 0.27 & 0.27 & n.a. & n.a. & n.a. & n.a. \\
\hline $\mathrm{X}_{\mathrm{Na}}$ & 0.05 & 0.03 & 0.04 & 0.04 & 0.78 & 0.78 & 0.72 & 0.72 & n.a. & n.a. & n.a. & n.a. \\
\hline $\mathrm{X}_{\mathrm{K}}$ & 0.95 & 0.97 & 0.96 & 0.96 & 0.00 & 0.01 & 0.01 & 0.01 & n.a. & n.a. & n.a. & n.a. \\
\hline $\mathrm{X}_{\mathrm{Fe}}$ & n.a. & n.a. & n.a. & n.a. & n.a. & n.a. & n.a. & n.a. & 0.48 & 0.68 & 0.43 & 0.44 \\
\hline$X_{\mathrm{Mg}}$ & n.a. & n.a. & n.a. & n.a. & n.a. & n.a. & n.a. & n.a. & 0.52 & 0.32 & 0.57 & 0.56 \\
\hline
\end{tabular}

N.B: * is used for geothermobarometric claculation; n.a.: Not Applicable 


\begin{tabular}{|c|c|c|c|c|c|c|c|c|c|c|c|}
\hline \multirow{2}{*}{$\begin{array}{l}\text { Rock type } \\
\text { Comment }\end{array}$} & \multicolumn{4}{|c|}{ TTGs } & \multicolumn{7}{|c|}{ high-K granitoids (hybrid granites) } \\
\hline & $\mathrm{Hbl}^{*}$ & $\mathrm{Hbl}$ & $\mathrm{Hbl}^{*}$ & $\mathrm{Hbl}$ & $\mathrm{Hbl}^{*}$ & Hbl core & $\mathrm{Hbl}^{*}$ & Hbl rim & Hbl core & $\mathrm{Hbl}^{*}$ & Hbl core \\
\hline $\mathrm{SiO}_{2}$ & 43.16 & 44.75 & 47.24 & 51.08 & 43.68 & 44.81 & 43.29 & 43.95 & 44.30 & 44.06 & 44.84 \\
\hline $\mathrm{TiO}_{2}$ & 0.97 & 2.11 & 0.52 & 0.25 & 0.92 & 0.75 & 0.94 & 1.07 & 0.80 & 0.80 & 0.96 \\
\hline $\mathrm{Al}_{2} \mathrm{O}_{3}$ & 9.16 & 8.04 & 6.49 & 3.83 & 8.42 & 7.93 & 8.45 & 8.51 & 8.38 & 8.56 & 8.14 \\
\hline $\mathrm{Cr}_{2} \mathrm{O}_{3}$ & 0.00 & 0.07 & 0.15 & 0.00 & 0.07 & 0.01 & 0.00 & 0.14 & 0.12 & 0.16 & 0.06 \\
\hline $\mathrm{FeO}$ & 19.36 & 18.13 & 18.88 & 15.25 & 20.08 & 20.49 & 20.76 & 19.76 & 20.36 & 20.26 & 20.16 \\
\hline $\mathrm{MnO}$ & 0.69 & 0.62 & 0.40 & 0.42 & 0.54 & 0.36 & 0.45 & 0.34 & 0.53 & 0.58 & 0.50 \\
\hline $\mathrm{MgO}$ & 11.67 & 11.67 & 12.99 & 15.58 & 10.13 & 10.59 & 10.09 & 10.38 & 10.34 & 10.29 & 10.64 \\
\hline $\mathrm{CaO}$ & 10.47 & 12.98 & 12.21 & 12.58 & 11.80 & 12.26 & 11.77 & 12.17 & 11.95 & 12.08 & 11.91 \\
\hline $\mathrm{Na}_{2} \mathrm{O}$ & 0.78 & 0.76 & 1.05 & 0.73 & 1.13 & 0.86 & 1.16 & 1.23 & 1.03 & 0.90 & 1.11 \\
\hline $\mathrm{K}_{2} \mathrm{O}$ & 2.00 & 0.69 & 0.61 & 0.29 & 0.99 & 0.77 & 0.97 & 0.98 & 0.88 & 1.00 & 0.91 \\
\hline $\mathrm{F}$ & 0.00 & 0.00 & 0.00 & 0.00 & 0.00 & 0.00 & 0.01 & 0.00 & 0.00 & 0.00 & 0.00 \\
\hline $\mathrm{P}_{2} \mathrm{O}_{5}$ & 0.00 & 0.02 & 0.00 & 0.00 & 0.00 & 0.03 & 0.00 & 0.03 & 0.00 & 0.03 & 0.00 \\
\hline $\mathrm{Cl}$ & 0.08 & 0.07 & 0.02 & 0.03 & 0.21 & 0.12 & 0.25 & 0.23 & 0.16 & 0.19 & 0.14 \\
\hline $\mathrm{ZnO}$ & 0.00 & 0.17 & 0.15 & 0.00 & 0.00 & 0.00 & 0.00 & 0.00 & 0.00 & 0.09 & 0.07 \\
\hline $\mathrm{BaO}$ & 0.00 & 0.00 & 0.00 & 0.00 & 0.04 & 0.00 & 0.00 & 0.04 & 0.00 & 0.01 & 0.00 \\
\hline Total & 98.35 & 100.08 & 100.67 & 99.74 & 98.01 & 98.96 & 98.11 & 98.81 & 98.83 & 99.01 & 99.42 \\
\hline $\mathrm{Si}$ & 6.43 & 6.56 & 6.85 & 7.30 & 6.57 & 6.64 & 6.52 & 6.57 & 6.59 & 6.55 & 6.63 \\
\hline $\mathrm{Al}^{\mathrm{iv}}$ & 1.57 & 1.39 & 1.11 & 0.64 & 1.43 & 1.36 & 1.48 & 1.43 & 1.41 & 1.45 & 1.37 \\
\hline $\mathrm{Ti}^{4+}$ & 0.00 & 0.05 & 0.04 & 0.06 & 0.00 & 0.00 & 0.00 & 0.00 & 0.00 & 0.00 & 0.00 \\
\hline $\mathrm{Fe}^{3+}$ & 0.00 & 0.00 & 0.00 & 0.00 & 0.00 & 0.00 & 0.00 & 0.00 & 0.00 & 0.00 & 0.00 \\
\hline Sum T & 8.00 & 8.00 & 8.00 & 8.00 & 8.00 & 8.00 & 8.00 & 8.00 & 8.00 & 8.00 & 8.00 \\
\hline Alvi & 0.04 & 0.00 & 0.00 & 0.00 & 0.07 & 0.02 & 0.02 & 0.06 & 0.05 & 0.05 & 0.04 \\
\hline $\mathrm{Ti}$ & 0.11 & 0.18 & 0.02 & 0.20 & 0.10 & 0.08 & 0.11 & 0.12 & 0.09 & 0.09 & 0.11 \\
\hline $\mathrm{Fe}^{3+}$ & 0.86 & 0.49 & 0.50 & 0.27 & 0.73 & 0.84 & 0.80 & 0.63 & 0.81 & 0.83 & 0.75 \\
\hline $\mathrm{Cr}$ & 0.00 & 0.01 & 0.03 & 0.00 & 0.01 & 0.00 & 0.00 & 0.02 & 0.02 & 0.03 & 0.01 \\
\hline $\mathrm{Mg}$ & 2.59 & 2.55 & 2.81 & 3.32 & 2.27 & 2.34 & 2.27 & 2.31 & 2.29 & 2.28 & 2.34 \\
\hline $\mathrm{Fe}^{2+}$ & 1.39 & 1.74 & 1.65 & 1.21 & 1.80 & 1.70 & 1.81 & 1.84 & 1.72 & 1.69 & 1.74 \\
\hline $\mathrm{Mn}^{3+}$ & 0.00 & 0.00 & 0.00 & 0.00 & 0.02 & 0.02 & 0.00 & 0.01 & 0.01 & 0.03 & 0.01 \\
\hline $\mathrm{Ca}$ & 0.00 & 0.03 & 0.00 & 0.00 & 0.00 & 0.00 & 0.00 & 0.00 & 0.00 & 0.00 & 0.00 \\
\hline Sum C & 5.00 & 5.00 & 5.00 & 5.00 & 5.00 & 5.00 & 5.00 & 5.00 & 5.00 & 5.00 & 5.00 \\
\hline $\mathrm{Mg}$ & 0.00 & 0.00 & 0.00 & 0.00 & 0.00 & 0.00 & 0.00 & 0.00 & 0.00 & 0.00 & 0.00 \\
\hline $\mathrm{Fe}^{2+}$ & 0.16 & 0.00 & 0.14 & 0.35 & 0.00 & 0.00 & 0.01 & 0.00 & 0.00 & 0.00 & 0.00 \\
\hline $\mathrm{Mn}^{2+}$ & 0.09 & 0.08 & 0.05 & 0.05 & 0.05 & 0.03 & 0.06 & 0.03 & 0.05 & 0.04 & 0.06 \\
\hline $\mathrm{Ca}$ & 1.67 & 1.92 & 1.81 & 1.60 & 1.90 & 1.94 & 1.90 & 1.95 & 1.90 & 1.93 & 1.89 \\
\hline $\mathrm{Na}$ & 0.08 & 0.00 & 0.00 & 0.00 & 0.05 & 0.03 & 0.04 & 0.02 & 0.05 & 0.03 & 0.06 \\
\hline Sum B & 2.00 & 2.00 & 2.00 & 2.00 & 2.00 & 2.00 & 2.00 & 2.00 & 2.00 & 2.00 & 2.00 \\
\hline $\mathrm{Na}$ & 0.15 & 0.22 & 0.30 & 0.20 & 0.28 & 0.22 & 0.30 & 0.34 & 0.25 & 0.23 & 0.26 \\
\hline $\mathrm{K}$ & 0.38 & 0.13 & 0.11 & 0.05 & 0.19 & 0.14 & 0.19 & 0.19 & 0.17 & 0.19 & 0.17 \\
\hline Vacant site & 0.00 & 0.10 & 0.09 & 0.33 & 0.00 & 0.00 & 0.00 & 0.00 & 0.00 & 0.00 & 0.00 \\
\hline
\end{tabular}

N.B: * is used for geothermobarometric claculation

except for a few places where depletion in concentration is noticed (Fig. 9-10).

In the case of LSHM (hybrid granites) high-K granitoids there is a visible decrease in the $\mathrm{Si}$, and $\mathrm{X}_{\mathrm{Mg}}$ near the grain boundary with respect to the core (Fig. 11-12). On the other hand, $\mathrm{Na}, \mathrm{X}_{\mathrm{Fe}}$ and $\mathrm{Al}_{\mathrm{T}}$ are much depleted in the core with variably enriched $\mathrm{Na}$ and $\mathrm{Al}_{\mathrm{T}}$ towards the rims. Ti shows uneven zoning throughout the grain with slight elemental enrichment towards one of the boundaries (Fig. 11-12) while $\mathrm{Ca}$ is comparatively homogeneous throughout the grain.

In the ternary projections the amphibole compositions are plotted using the tremolite and $\mathrm{NaAlSi}_{-1}$ exchange parameters along with kaersutite $\left(\mathrm{NaTiAl}_{2} \mathrm{Mg}_{-1} \mathrm{Si}_{2} \mathrm{H}_{-1}\right)$, and $\mathrm{KNa}_{-1}$ exchange vectors in the upper and lower plots respectively (Fig. 13). The components are as follows:

tremolite $=\mathrm{Ca}_{2} \mathrm{Mg}_{5} \mathrm{Si}_{8} \mathrm{O} 22(\mathrm{OH})_{2} ; \mathrm{Na}-\mathrm{Ged}=\mathrm{Na}$-gedrite, $\mathrm{NaMg}_{6} \mathrm{Al}-$ 

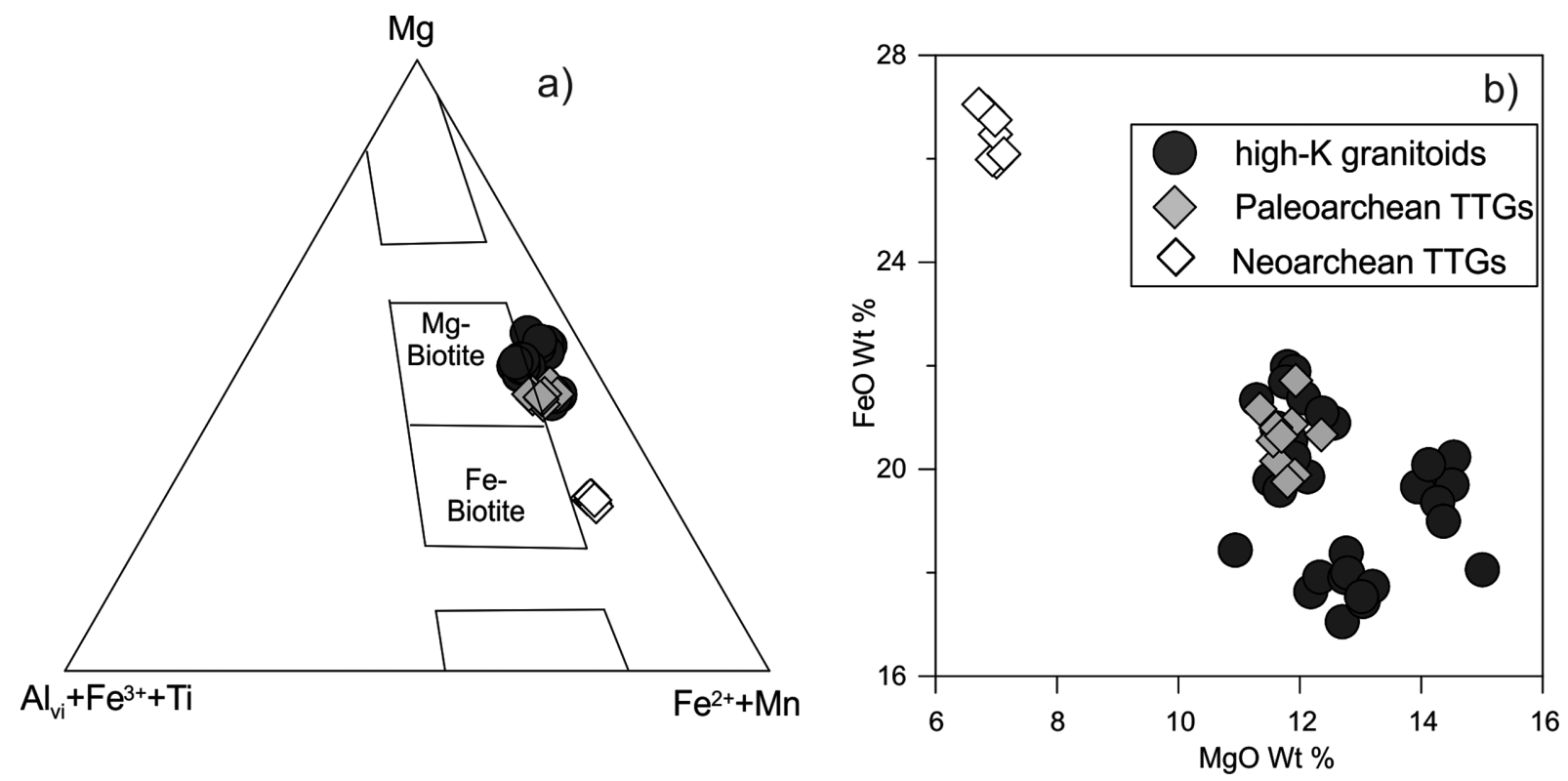

Figure 6. a) Classification of biotite by chemical and lithological affinity (adapted from Foster, 1960); b) Major element binary plot showing variations in biotite from the $B C$.
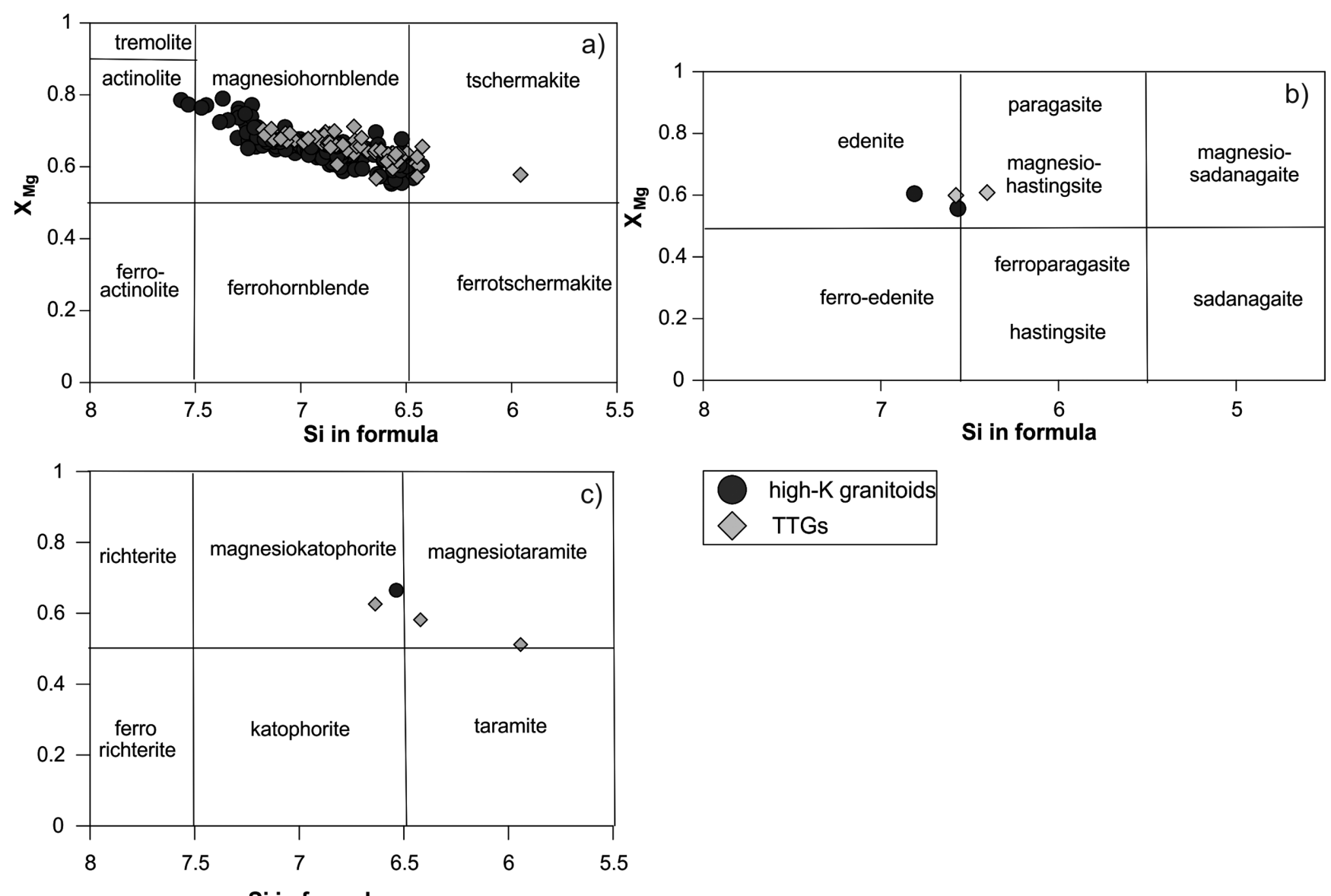

Si in formula

Figure 7. a, b) Composition of calcic amphiboles; c) sodic-calcic amphiboles from BC following the classification of Leake (1978) and Leake et al. (1997).

$\mathrm{Si}_{6} \mathrm{Al}_{2} \mathrm{O}_{22}(\mathrm{OH})_{2} ;$ Parg = pargasite, $\mathrm{NaCa}_{2}\left(\mathrm{Mg}_{4} \mathrm{Al}\right) \mathrm{Si}_{6} \mathrm{Al}_{2} \mathrm{O}_{22}(\mathrm{OH})_{2} ; \mathrm{K}-$ Ged = K-gedrite, $\mathrm{KMg}_{6} \mathrm{AlSi}_{6} \mathrm{Al}_{2} \mathrm{O}_{22}(\mathrm{OH})_{2} ;$ Kaers = kaersutite, $\mathrm{NaCa}_{2}\left(\mathrm{Mg}_{4} \mathrm{Ti}\right)$ $\mathrm{Si}_{6} \mathrm{Al}_{2} \mathrm{O}_{23}(\mathrm{OH})_{2} ; \mathrm{K}$-Ed = K-edenite, $\mathrm{KCa}_{2} \mathrm{Mg}_{5} \mathrm{Si}_{7} \mathrm{AlO}_{22}(\mathrm{OH})_{2}$; in each of these components, $\mathrm{Mg}$ can be replaced by $\mathrm{Fm}$, where $\mathrm{FmO}=\mathrm{FeO}$ $+\mathrm{MgO}$, and a Fe- $\mathrm{Mg}$ exchange parameter, $\mathrm{Mg}_{-1} \mathrm{Fe}$ is then added to a component like tremolite, to make tremolite-ferro-actinolite. Putirka 
TTGs (a-e)
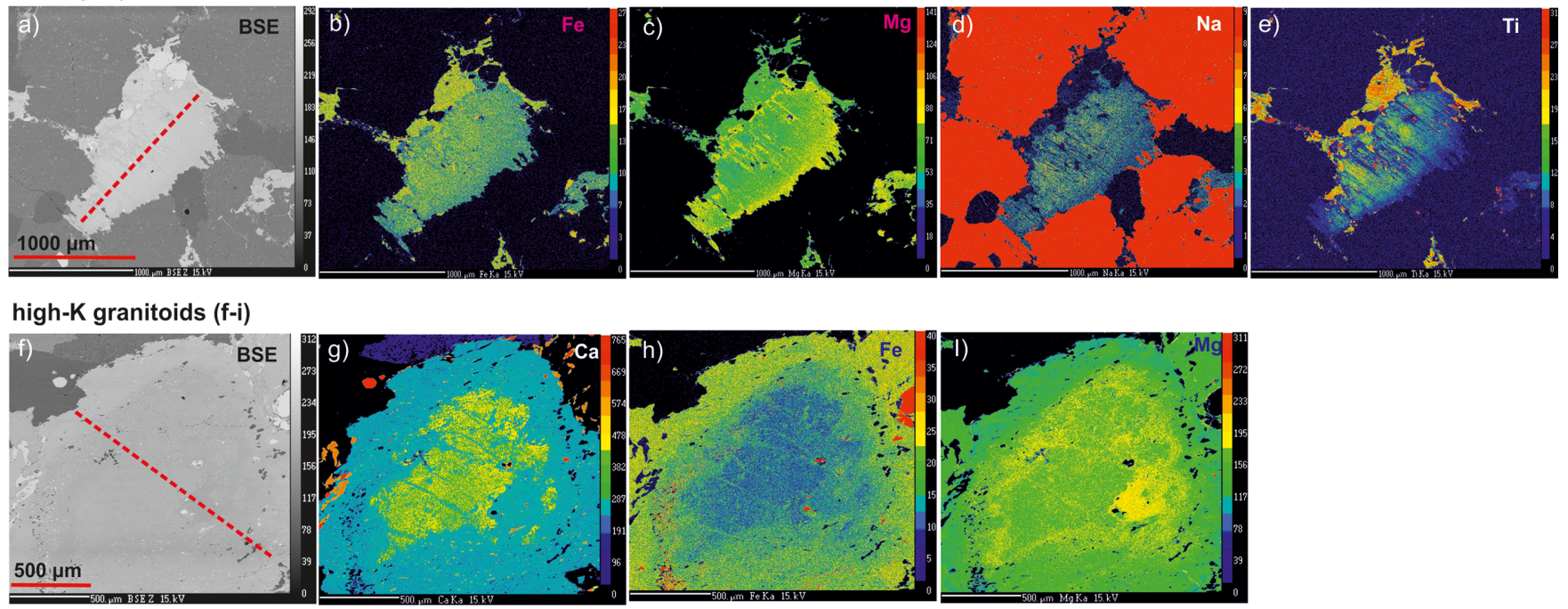

Figure 8. BSE images and X-ray elemental maps of amphiboles from TTGs (a-e)andLSHM high-K grantoids (hybrid granites) (f-i) from BC. Measured rim to rim profile is marked as red dotted line in BSE images.
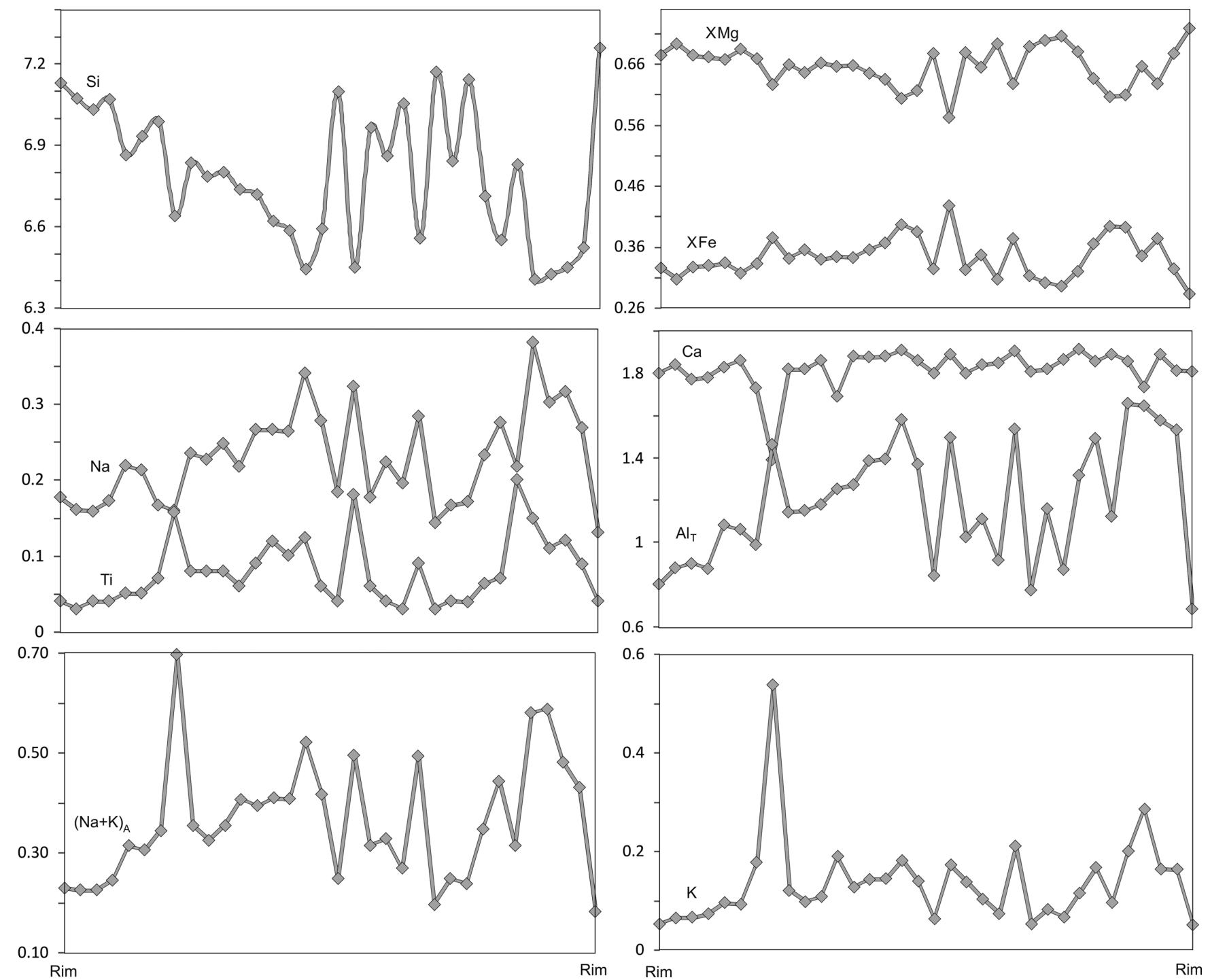

Figure 9. Elemental line profile (rim to rim) plots of amphibole (shown in Fig. 7b-e) from TTG The profile is marked in Fig. 7. 

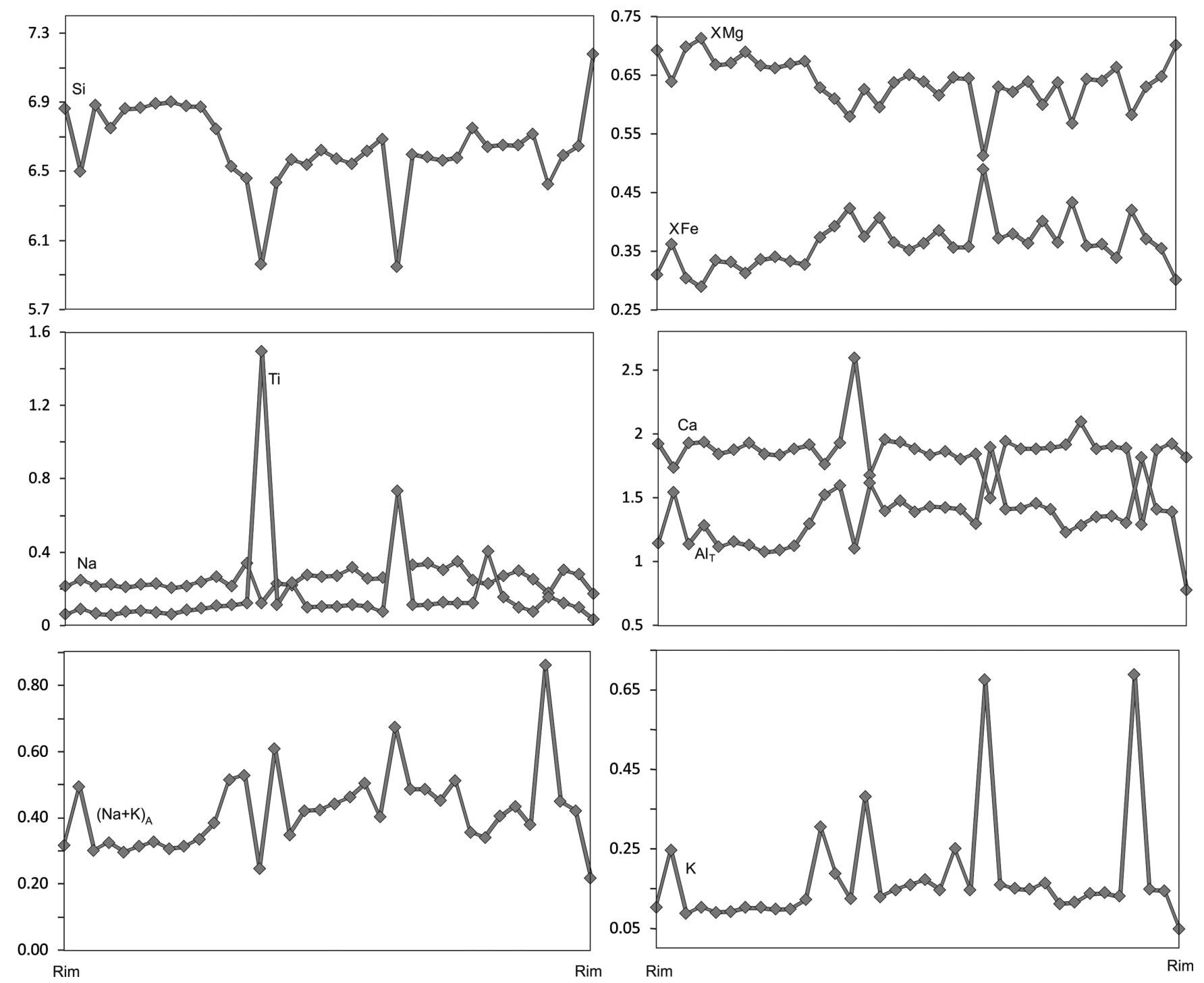

Figure 10. Elemental line profile (rim to rim) plots of amphibole (second grain; not shown in Fig) from TTG.

(2016) showed that adding Fe, shifts components toward the tremolite corners, without affecting component trajectories, thereby mostly $\mathrm{Fe} / \mathrm{Mg}$ ratios do not affect other substitution mechanisms.

Both plots (Fig. 13) exhibit that the studied amphiboles of TTGs as well as LSHM (hybrid granites) high-K granitoids have similar compositions coupled with the same stoichiometric substitutional mechanisms which support the analytical and experimental work of Putirka, (2016). In our study, it is to be noted that the occurrence of extensive Fe-Mg exchange makes the plot of the amphibole composition towards the tremolite-ferro-actinolite corner.

However, The studied amphibole (Table 3b and S-4) in TTGs and LSHM (hybrid granites) high-K granitoids is considered magmatic due to the following reasons: a) texturally coarse-grained amphiboles have straight grain margins with perthites, and these are generally not foliation defining, b) moderately oscillatory compositional variation (e.g., Al; Fig. 9-10), c) the amphibole compositions plot falls in the igneous field, both in the $\mathrm{Ca}+\mathrm{Na}+\mathrm{K}$ versus $\mathrm{Si}$ diagram (Fig. 14) as well as, $\mathrm{Al}_{\mathrm{vi}}$ vs $\mathrm{Al}_{\mathrm{iv}}$ plot (Fig not shown as a majority of amphiboles have very low $\mathrm{Al}_{\mathrm{vi}}$ contents). On the other hand, less abundant fine-grained amphi- boles, those lying outside the shaded area in Fig. 14, can be formed due to the low-grade metamorphism; and we are not considering them in our discussion on magma evolution.

\section{Geothermobarometry}

Generally, the depth of crystallization and emplacement of granitic plutons can be assessed using the $\mathrm{Al}$ in hornblende barometer for metaluminous granites when appropriately corrected for temperature (Anderson et al., 2008). Because, Al content of hornblende in calcalkaline granitoids varies linearly with the pressure of crystallization and is controlled by the pressure-dependent Tschermak substitution (Stein and Dietl, 2001); providing a means of determining the depth of emplacement (e.g., Vyhnal et al., 1991). Solidus pressures of calcalkaline plutons can be estimated by hornblende composition, using different calibrations suggested for Al-in-hornblende geobarometry (Hammarstrom and Zen, 1986; Schmidt, 1992; and Anderson and Smith, 1995). Schimdt (1992) experimentally calibrated Al-in-hornblende 

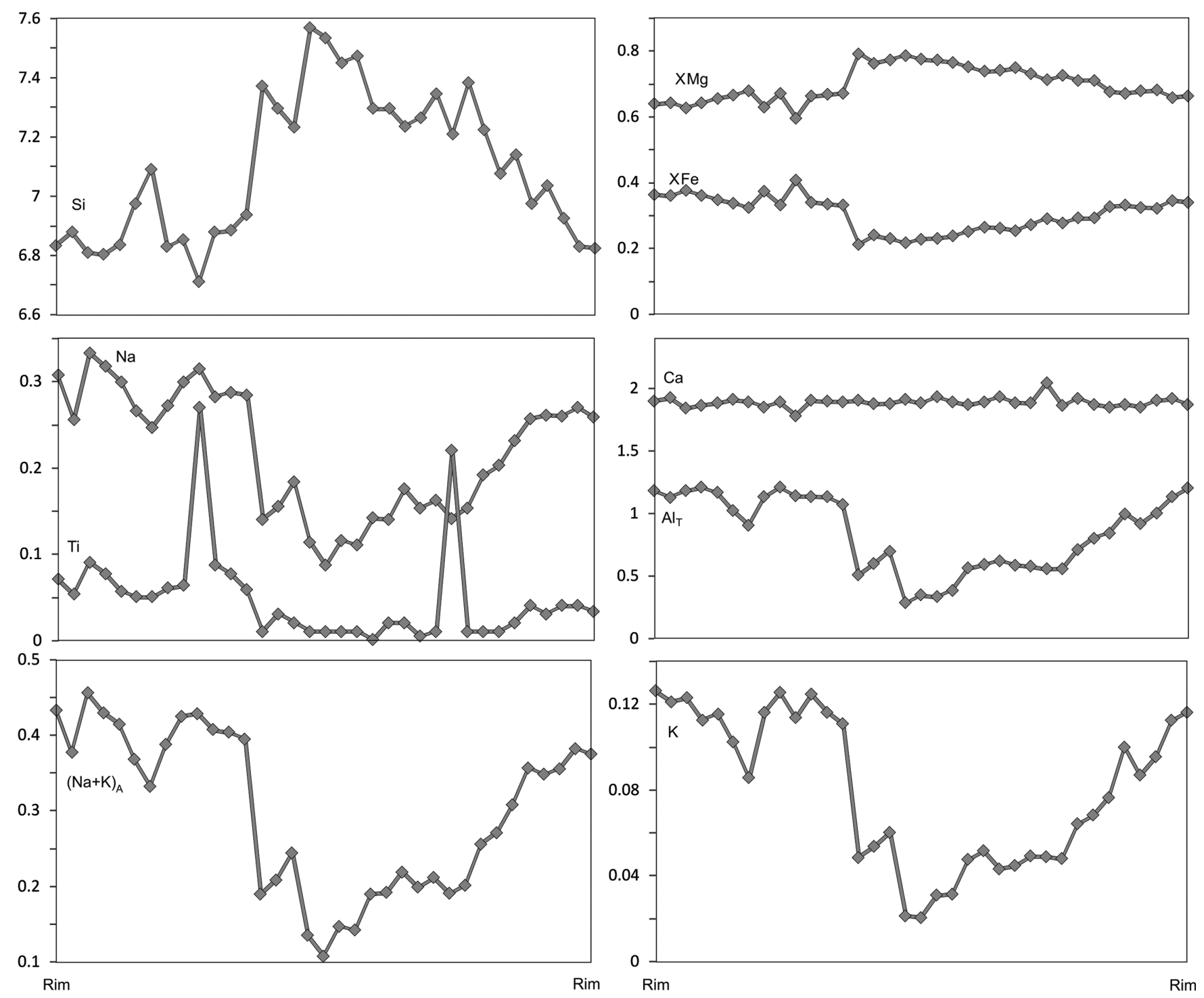

Figure 11. Elemental line profile (rim to rim) plots of amphibole (shown in Fig. 7g-i) from LSHM (hybrid granites) high-K grantoids.

barometer which correlates total $\mathrm{Al}$ content in hornblende with crystallization pressure of intrusion (Hammarstrom and Zen, 1986), under water-saturated conditions at pressures of 2.5-13 kbar and temperatures of $700-655^{\circ} \mathrm{C}$. But Blundy and Holland (1990) emphasized that temperature plays a more important role for the Al-content of amphiboles; therefore Anderson and Smith (1995) suggested a new formulation of the Al-in-hornblende barometer considering all the three intensive parameters like, pressure, temperature and oxygen fugacity which control the $\mathrm{Al}$ content of hornblendes. The recalibration of Anderson and Smith (1995) is based on the Al-in hornblende barometers of Johnson and Rutherford (1989) and Schmidt (1992) by introducing a temperature correction term based on the amphibole-plagioclase thermometer of Blundy and Holland (1990).

In the present study, the pressure of the TTGs and LSHM (hybrid) high-K granitoids from the $\mathrm{BC}$ is obtained using amphibole compositions (Table $3 \mathrm{a}$ and 4). The average $\mathrm{Al}_{\text {total }}$ contents of hornblendes of TTGs and LSHM (hybrid granites) high-K granitoids are 1.27 and 1.12 respectively. Consequently, pressures without applying the tem- perature correction (Anderson and Schmidt, 1995) for the TTGs range from 4.13 kbar to 4.65 kbar; while LSHM (hybrid granites) high-K granitoids shows the range from 1.59 to $4.18 \mathrm{kbar}$. Since the amphibole-plagioclase thermometer of Blundy and Holland (1990) yielded temperatures which are significantly above the solidus (viz. TTGs: $761^{\circ} \mathrm{C}$, LSHM (hybrid granites) high-K granitoids: $745^{\circ} \mathrm{C}$ ), a temperature correction, according to Anderson and Smith (1995), seems to be reasonable as suggested by Stein and Dietl (2001). This correction generally leads to lower pressure values of $\sim 3.21 \mathrm{kbar}$ for TTGs and $\sim 2.56$ kbar for LSHM (hybrid granites) high-K granitoids (Table 4).

However, using all these calibrations, our study shows that the estimated average pressures for TTGs $(\mathrm{P}=4.10 \pm 0.20 \mathrm{kbar})$ are higher than that for the LSHM (hybrid granites) high-K granitoids ( $\mathrm{P}=3.06$ $\pm 0.40 \mathrm{kbar}$ ) (Table 4 ) which points towards a greater depth of crystallization ( $\sim 16 \mathrm{~km})$ for the TTGs compare to that of LSHM (hybrid granites) high-K granitoids $(\sim 12 \mathrm{~km})$.

Although the amphibole-plagioclase thermometer is still under debate, there is no other geothermometer that can be applied to calc-alkaline 

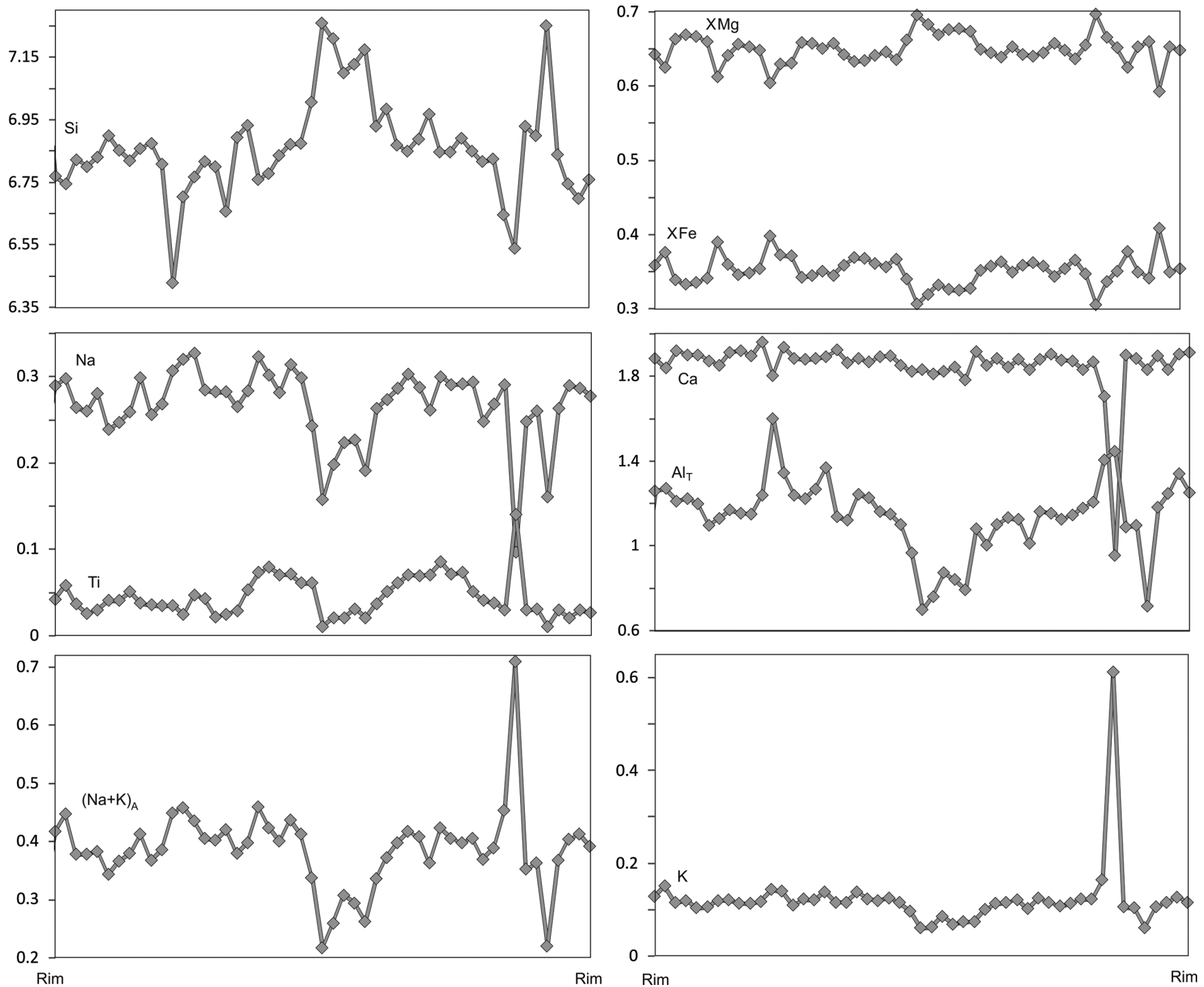

Figure 12. Elemental line profile (rim to rim) plots of amphibole (second grain; Fig not shown) from LSHM (hybrid granites) high-K granitoids.

igneous rocks (Stein and Dietl, 2001). Therefore, hornblende and plagioclase pairs which coexist in the granitoids are used for thermometry calculations as suggested by Blundy and Holland (1990). They proposed a very simple, empirical thermometer on the basis of the edenite-tremolite reaction, applicable for quartz-bearing, intermediate to felsic igneous rocks with plagioclase $\mathrm{An} \leq 0.92$ and $\mathrm{Si}$ in hornblende $\leq 7.8$ atoms p.f.u. This thermometer is calibrated for temperatures between $500^{\circ} \mathrm{C}$ and $1100^{\circ} \mathrm{C}$. The calculated crystallisation temperatures like $760 \pm 2^{\circ} \mathrm{C}$ and $745 \pm 12^{\circ} \mathrm{C}$ for TTGs and LSHM (hybrid granites) high-K granitoids respectively, are nearly similar (Table 4 ).

Erdmann et al. (2014) show that the use of amphibole as geobarometer does not apply to an igneous system on account of Al-substitution in amphibole being largely temperature-sensitive other than in a window defined by temperatures $<800^{\circ} \mathrm{C}$ and $\mathrm{Fe} \#(\mathrm{Fe} / \mathrm{Fe}+\mathrm{Mg})$ of the amphiboles below 0.65 . The $\mathrm{BC}$ amphiboles from both TTGs as well as LSHM (hybrid granites) high-K granitoids lie within this window and the inferred crystallization depth are considered reliable.

\section{Discussion}

\section{Mineral Chemistry and Substitution Vectors}

Microprobe analyses of biotite (Table 3a; S-3) from the BC indicate low alumina saturation index $\left(\mathrm{Al}_{\mathrm{T}} / \mathrm{Ca}+\mathrm{Na}+\mathrm{K}, \mathrm{ASI}=1.13-1.74\right)$ of the studied biotites, which reflects decreased alumina activity in the crystallising magma (Zen, 1988). The average value of $\mathrm{FeO}(\mathrm{t}) / \mathrm{MgO}$ ratio of biotite in the $\mathrm{BC}$ is 2.04 (the ratio ranging from 1.20 to 4.03 ) which is higher than the average value of 1.76 for $\mathrm{FeO}(\mathrm{t}) / \mathrm{MgO}$ ratio obtained from the Mg-biotites in Abdel-Rahman (1994); the latter being typically associated with calcic-pyroxene/calcic amphibole in the calcalkaline I-type granitoid suites (formed mostly in an orogenic and subduction-related tectonic setting). Thus, in our work, the studied biotite association along with the calc-amphiboles is consistent with the findings of Abdel-Rahman (1994), thereby suggesting the crystallisation 


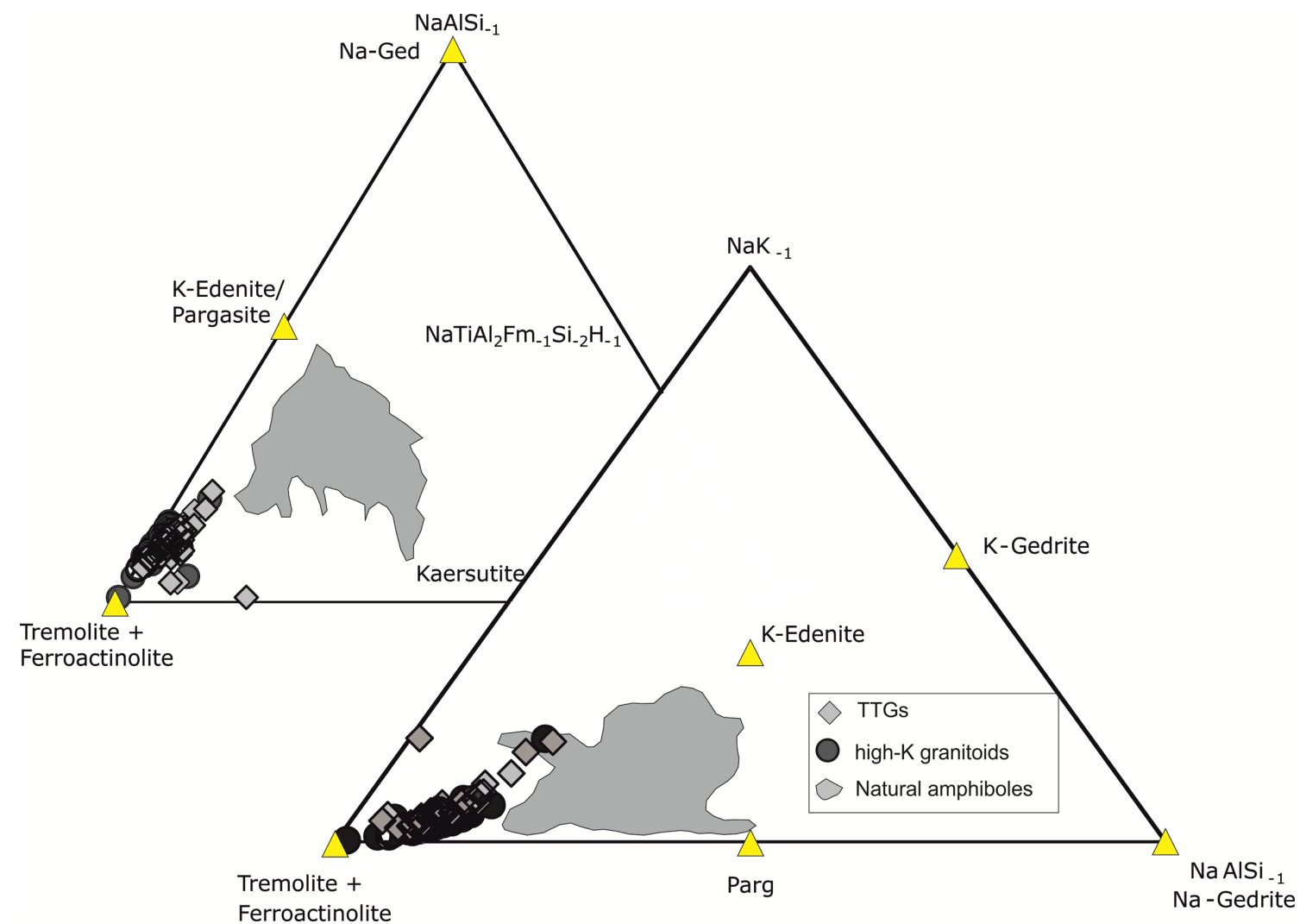

Figure 13. Ternary projections of experimental and Bundelkhand amphibole compositions, (after Putrika, 2016). In both figures, amphibole

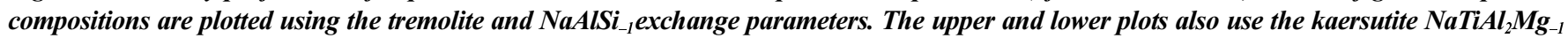
$\mathrm{Si}_{-2} \mathrm{H}_{-1}$, and $\mathrm{NaK}_{-}$exchange parameters. The components are as follows: tremolite $=\mathrm{Ca}_{2} \mathrm{Mg}_{3} \mathrm{Si}_{8} \mathrm{O}_{22}(\mathrm{OH})_{2} ; \mathrm{Na}-\mathrm{Ged}=\mathrm{Na}-\mathrm{gedrite}, \mathrm{NaMg}_{6} \mathrm{AlSi} \mathrm{i}_{6} \mathrm{Al}_{2} \mathrm{O}_{22}(\mathrm{OH})_{2}$; Parg = pargasite, $\mathrm{NaCa}_{2}\left(\mathrm{Mg}_{4} \mathrm{Al}\right) \mathrm{Si}_{6} \mathrm{Al}_{2} \mathrm{O}_{22}(\mathrm{OH})_{2} ; \mathrm{K}$-Ged = K-gedrite, $\mathrm{KMg}_{6} \mathrm{AlSi}_{6} \mathrm{Al}_{2} \mathrm{O}_{22}(\mathrm{OH})_{2} ; \mathrm{Kaers}=\mathrm{kaersutite}, \mathrm{NaCa}_{2}\left(\mathrm{Mg}_{4} \mathrm{Ti}\right) \mathrm{Si}_{6} \mathrm{Al} \mathrm{O}_{23}(\mathrm{OH})_{2}$; $\mathrm{K}-\mathrm{Ed}=\mathrm{K}$-edenite, $\mathrm{KCa}_{2} \mathrm{Mg}_{5} \mathrm{Si}_{7} \mathrm{AlO}_{22}(\mathrm{OH})_{2}$. The data for natural amphiboles is taken from Putrika (2016).

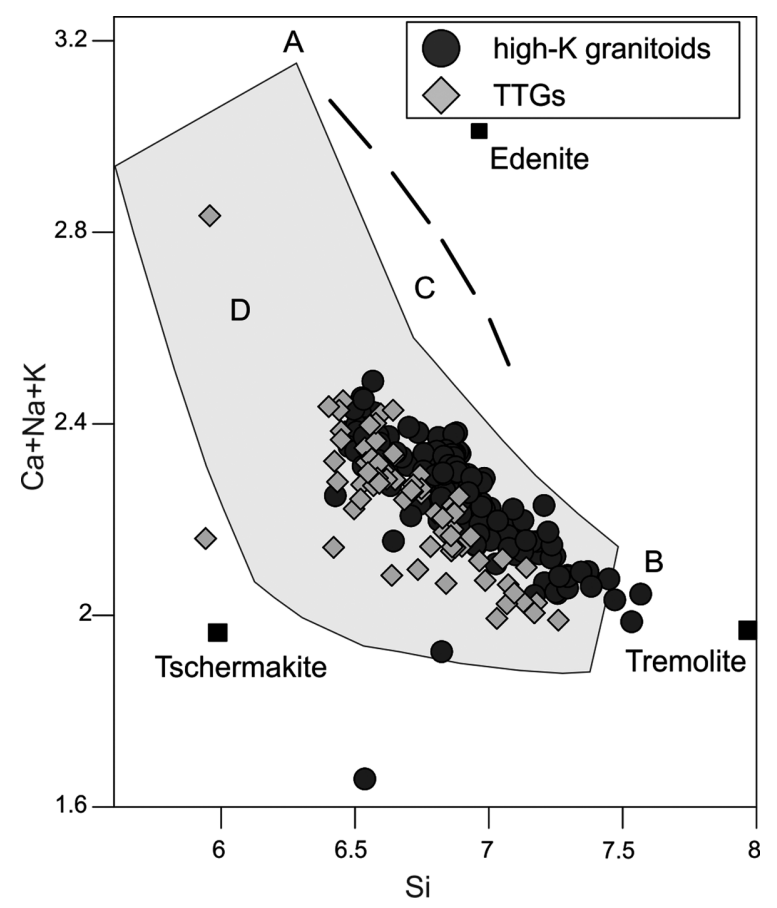

Figure 14. Plot of $(\mathrm{Ca}+\mathrm{Na}+\mathrm{K})$ vs Si for the studied amphiboles from $B C$. Curved line $A B$ indicates suggested limits of igneous ambhiboles. Field C contains and D after Leake (1971). of studied biotite in a calc-alkaline suite. The feature, that the host granitoids in the $\mathrm{BC}$ is calc-alkaline, is also corroborated by the previously reported bulk-rock geochemical data (Mondal et al., 2002; Kaur et al., 2016; Joshi et al., 2017). On the other hand, according to the experiments of Wones and Eugster (1965), biotite crystallizing in the presence of $\mathrm{K}$-feldspar and magnetite can be rich either in $\mathrm{Fe}$ or $\mathrm{Mg}$ depending upon the partial pressure of oxygen during the cooling of the melt. During the crystallization, under oxidising condition biotite becomes Mg-enriched with a considerable amount of modal magnetite, whereas under reducing condition biotite gets enriched in $\mathrm{Fe}$, with a scarce amount of magnetite. Therefore, the formation of Mg-biotite with calc-alkaline nature can be a result of oxygen-rich environment created due to early dissociation of water and release of $\mathrm{H}$ and $\mathrm{O}$. This oxygen, in addition, causes early crystallisation of iron-rich amphibole and iron oxides (typically magnetite), thereby precluding the build-up of iron in the calc-alkaline melt, and causing crystallization of moderately Mgrich biotite (Lalonde and Bernard, 1993; Abdel-Rahman, 1994; Shabani and Lalonde, 2003; Masoudi and Badr, 2008). Compatible with the preceding discussion, our data from $\mathrm{Mg}$ - and Fe-biotite suggest that the crystallisation condition of magma changed during Archaean. For instance, there was oxidising condition during Paleoarchaean, followed by reducing at the beginning of Neoarchaean, and finally reverted to oxidising (again), near the Archaean Proterozoic transition. Nevertheless, negative correlation between $\mathrm{MgO}$ and $\mathrm{FeO}$ of the studied biotites suggests that temperature-dependent $\mathrm{Mg}$-Fe substitution may have also 
Table 4. Results of thermobarometric calculations on TTGs and LSHM (hybrid granites) high-K granitoids using different models of thermobarometers

\begin{tabular}{|c|c|c|c|}
\hline Sample & Method & $\mathrm{P}[\mathrm{kbar}]$ & $\mathrm{T}\left[{ }^{\circ} \mathrm{C}\right]$ \\
\hline \multirow{4}{*}{ BETTG133 TTG (a) } & Schmidt, 1992 & 4.65 & 758 \\
\hline & Hollister et al., 1987 & 4.41 & 761 \\
\hline & Hammaerstorm and Zen, 1986 & 4.18 & 765 \\
\hline & Anderson and Smith, (1995) & 3.13 & $(761)$ \\
\hline \multirow{4}{*}{ BETTG107 TTG (b) } & Schmidt, 1992 & 4.61 & 756 \\
\hline & Hollister et al., 1987 & 4.35 & 760 \\
\hline & Hammaerstorm and Zen, 1986 & 4.13 & 764 \\
\hline & Anderson and Smith, (1995) & 3.29 & $(761)$ \\
\hline TTGs & \multicolumn{3}{|c|}{ Average $\mathrm{P}=4.10 \pm 0.20 \mathrm{kbar}$ and $\mathrm{T}=760 \pm 2{ }^{\circ} \mathrm{C}$} \\
\hline \multirow{4}{*}{$\begin{array}{l}\text { BCTG } 129 \text { high-K } \\
\text { granitoid (a) }\end{array}$} & Schmidt, 1992 & 2.7 & 718 \\
\hline & Hollister et al., 1987 & 2.1 & 726 \\
\hline & Hammaerstorm and Zen, 1986 & 2.11 & 726 \\
\hline & Anderson and Smith, (1995) & 1.79 & $(750)$ \\
\hline \multirow{4}{*}{$\begin{array}{l}\text { BCTG } 129 \text { high-K } \\
\text { granitoid (b) }\end{array}$} & Schmidt, 1992 & 2.5 & 692 \\
\hline & Hollister et al., 1987 & 1.85 & 700 \\
\hline & Hammaerstorm and Zen, 1986 & 1.9 & 700 \\
\hline & Anderson and Smith, (1995) & 1.61 & $(750)$ \\
\hline \multirow{4}{*}{$\begin{array}{l}\text { BCTG } 129 \text { high-K } \\
\text { granitoid (c) }\end{array}$} & Schmidt, 1992 & 2.27 & 710 \\
\hline & Hollister et al., 1987 & 1.59 & 719 \\
\hline & Hammaerstorm and Zen, 1986 & 1.66 & 718 \\
\hline & Anderson and Smith, (1995) & 1.4 & $(750)$ \\
\hline \multirow{4}{*}{$\begin{array}{l}\text { BSTG } 120 \text { high-K } \\
\text { granitoid }(\mathrm{d})\end{array}$} & Schmidt, 1992 & 4.13 & 752 \\
\hline & Hollister et al., 1987 & 3.79 & 757 \\
\hline & Hammaerstorm and Zen, 1986 & 3.63 & 760 \\
\hline & Anderson and Smith, (1995) & 3.08 & $(750)$ \\
\hline \multirow{4}{*}{$\begin{array}{l}\text { BSTG } 120 \text { high-K } \\
\text { granitoid (e) }\end{array}$} & Schmidt, 1992 & 4.13 & 763 \\
\hline & Hollister et al., 1987 & 3.79 & 768 \\
\hline & Hammaerstorm and Zen, 1986 & 3.62 & 770 \\
\hline & Anderson and Smith, (1995) & 3.08 & $(750)$ \\
\hline \multirow{4}{*}{$\begin{array}{l}\text { BSTG } 120 \text { high-K } \\
\text { granitoid (f) }\end{array}$} & Schmidt, 1992 & 4.13 & 759 \\
\hline & Hollister et al., 1987 & 3.79 & 764 \\
\hline & Hammaerstorm and Zen, 1986 & 3.63 & 767 \\
\hline & Anderson and Smith, (1995) & 3.08 & $(750)$ \\
\hline \multirow{4}{*}{$\begin{array}{l}\text { BSTG } 119 \text { high-K } \\
\text { granitoid }(\mathrm{g})\end{array}$} & Schmidt, 1992 & 4.03 & 761 \\
\hline & Hollister et al., 1987 & 3.68 & 767 \\
\hline & Hammaerstorm and Zen, 1986 & 3.52 & 769 \\
\hline & Anderson and Smith, (1995) & 2.99 & $(750)$ \\
\hline \multirow{4}{*}{$\begin{array}{l}\text { BSTG } 119 \text { high K } \\
\text { granitoid }(h)\end{array}$} & Schmidt, 1992 & 3.94 & 742 \\
\hline & Hollister et al., 1987 & 3.56 & 747 \\
\hline & Hammaerstorm and Zen, 1986 & 3.42 & 750 \\
\hline & Anderson and Smith, (1995) & 2.91 & $(750)$ \\
\hline \multirow{4}{*}{ BSTG 119 high-K granitoid (i) } & Schmidt, 1992 & 4.18 & 771 \\
\hline & Hollister et al., 1987 & 3.85 & 776 \\
\hline & Hammaerstorm and Zen, 1986 & 3.68 & 779 \\
\hline & Anderson and Smith, (1995) & 3.12 & $(750)$ \\
\hline
\end{tabular}

( ): estimated T for calculation.

played an important role during the formation of the TTGs and LSHM (hybrid granites) high-K granitoids of the $\mathrm{BC}$.
In the case of amphibole, present in the studied rocks, several substitution mechanisms in amphibole involve the coupling of cations with 

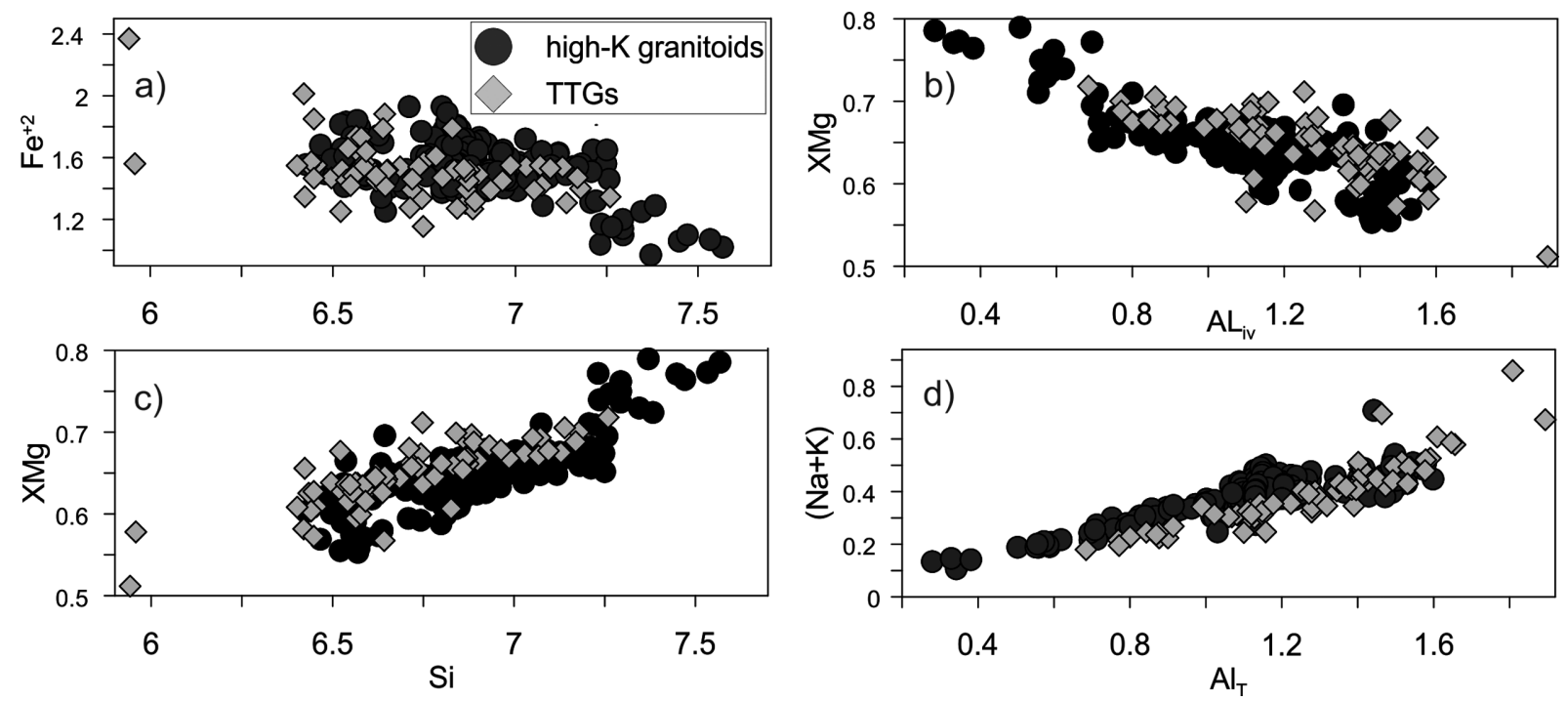

Figure 15. a-d) Variation diagrams of amphibole from TTGs and LSHM (hybrid granites) high-K grantoids, BC. For references please see associated text.
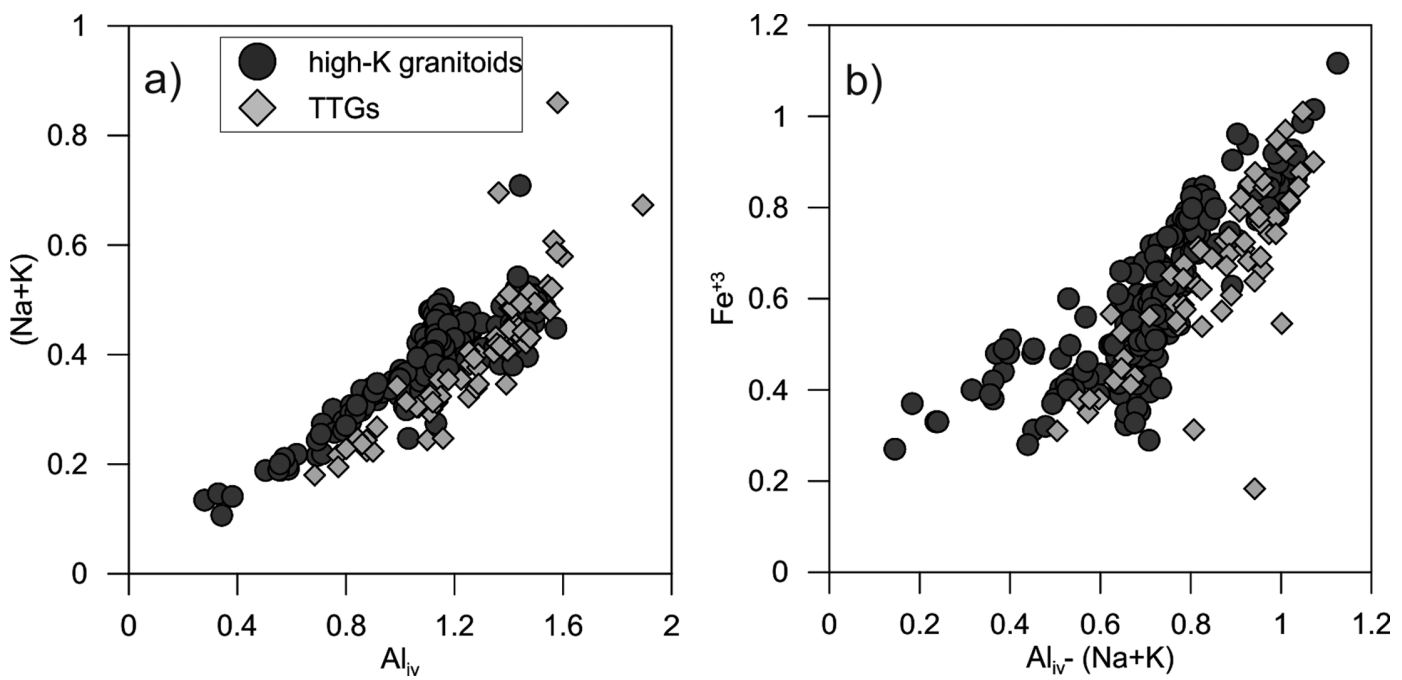

Figure 16. a-b) Chemical compositions of amphiboles described by variation diagrams. For references please see associated text.

different valence states (Vyhnal et al., 1991) to maintain charge balance. Variations in amphibole composition could be the outcome of such ion substitutions occurring at variable pressure and temperature conditions (Kostyuk and Sobolev, 1969; Moyes, 1991; Gilbert et al., 1982; Hammerstrom and Zen, 1986; Vyhnal et al., 1991). The observed variation in the studied amphibole chemistry is evaluated and is illustrated through common cation and coupled substitution diagrams (Fig.15, 16 and 17). We find a positive correlation between $\mathrm{Na}+\mathrm{K}$ and $\mathrm{Al}_{\mathrm{iv}}$, $\mathrm{Fe}^{+3}$ and $\mathrm{Al}_{\mathrm{iv}}-(\mathrm{Na}+\mathrm{K})$ (Fig. 16a,b) indicating substitution of $\mathrm{Na}_{\mathrm{iv}} \mathrm{Al}=\square$ $\mathrm{Si}$ ( $\square$ indicates vacancy in A site) and also $\mathrm{Fe}^{+3} \mathrm{Al}=\mathrm{MgSi}$. Although, Leake (1965) plotted $\mathrm{Al}_{\mathrm{vi}}$ against $\mathrm{Al}_{\mathrm{iv}}$ of calcic amphiboles from metamorphic and igneous rocks and suggested $2 \mathrm{Al}_{\mathrm{vi}}=\mathrm{MgSi}$ substitution, such a substitution is unfeasible in the studied amphiboles due to very low contents of $\mathrm{Al}_{\mathrm{vi}}$. However, our data reveal the occurrence of various ion substitutions (Fig. 17a-h) which played a dominant role in the formation of zoned amphiboles in the $\mathrm{BC}$; these substitutions are as follows: iron tschermakite $\left(\mathrm{Si}+\mathrm{Mg}-\mathrm{Al}_{\mathrm{iv}}+\mathrm{Fe}^{+3}\right)$, aluminium tschermakite ( $\left.\mathrm{Si}+\mathrm{Mg}-\mathrm{Al}_{\mathrm{T}}\right)$, titanium tschermakite $\left(\mathrm{Si}+\mathrm{Mg}-\mathrm{Al}_{\mathrm{iv}}+\mathrm{Ti}\right)$, hastingsite $(\square$
$\left.+\mathrm{Mg}+\mathrm{Si}-\mathrm{Na}_{\mathrm{A}}+\mathrm{Fe}^{+3}+\mathrm{Al}_{\mathrm{iv}}\right)$, pargasite $\left(\square+\mathrm{Mg}+\mathrm{Si}-\mathrm{Na}_{\mathrm{A}}+\mathrm{Al}_{\mathrm{T}}\right)$, edenite $(\square$ $\left.+\mathrm{Si}-\mathrm{Na}_{\mathrm{A}}+\mathrm{Al}_{\mathrm{iv}}\right)$, riebeckite $\left(\mathrm{Ca}+\mathrm{Mg}-\mathrm{Na}_{\mathrm{B}}+\mathrm{Fe}^{+3}\right)$ and glaucophane $(\mathrm{Ca}+$ $\left.\mathrm{Mg}-\mathrm{Na}_{\mathrm{B}}+\mathrm{Al}_{\mathrm{vi}}\right)$. It is to be noted that riebeckite substitution is predominant in TTGs compared to LSHM (hybrid granites) high-K granitoids (Fig. 17g). Amphibole in association with plagioclase has corrugated boundaries causing the replacement of amphibole which further suggests the combination of edenite and glaucophane substitution (Fig. 4f). There is a negative correlation between $\mathrm{Mg}$ and $\mathrm{Al}_{\mathrm{iv}}$ (Fig. 15b), and the increase in $\mathrm{Mg} /\left(\mathrm{Mg}+\mathrm{Fe}^{+2}\right)$, which reflects increasing oxygen fugacity as the magma became more siliceous (Fig. 15c; Campos et al., 2005 and references therein). Kostyuk and Sobolev (1969) and Vyhnal et al. (1991) pointed out that $\mathrm{Al}_{\mathrm{iv}}$ and alkalis decrease with decreasing temperature of formation, on the other hand, $\mathrm{Al}_{\mathrm{vi}}$ increases significantly with increasing pressure (Deer et al., 1997 and references therein). Since an increase in pressure is accompanied by an increase in $\mathrm{Al}_{\mathrm{vi}}$ contents; low $\mathrm{Al}_{\mathrm{vi}}$ in studied amphiboles suggest that they formed in low-pressure conditions. 

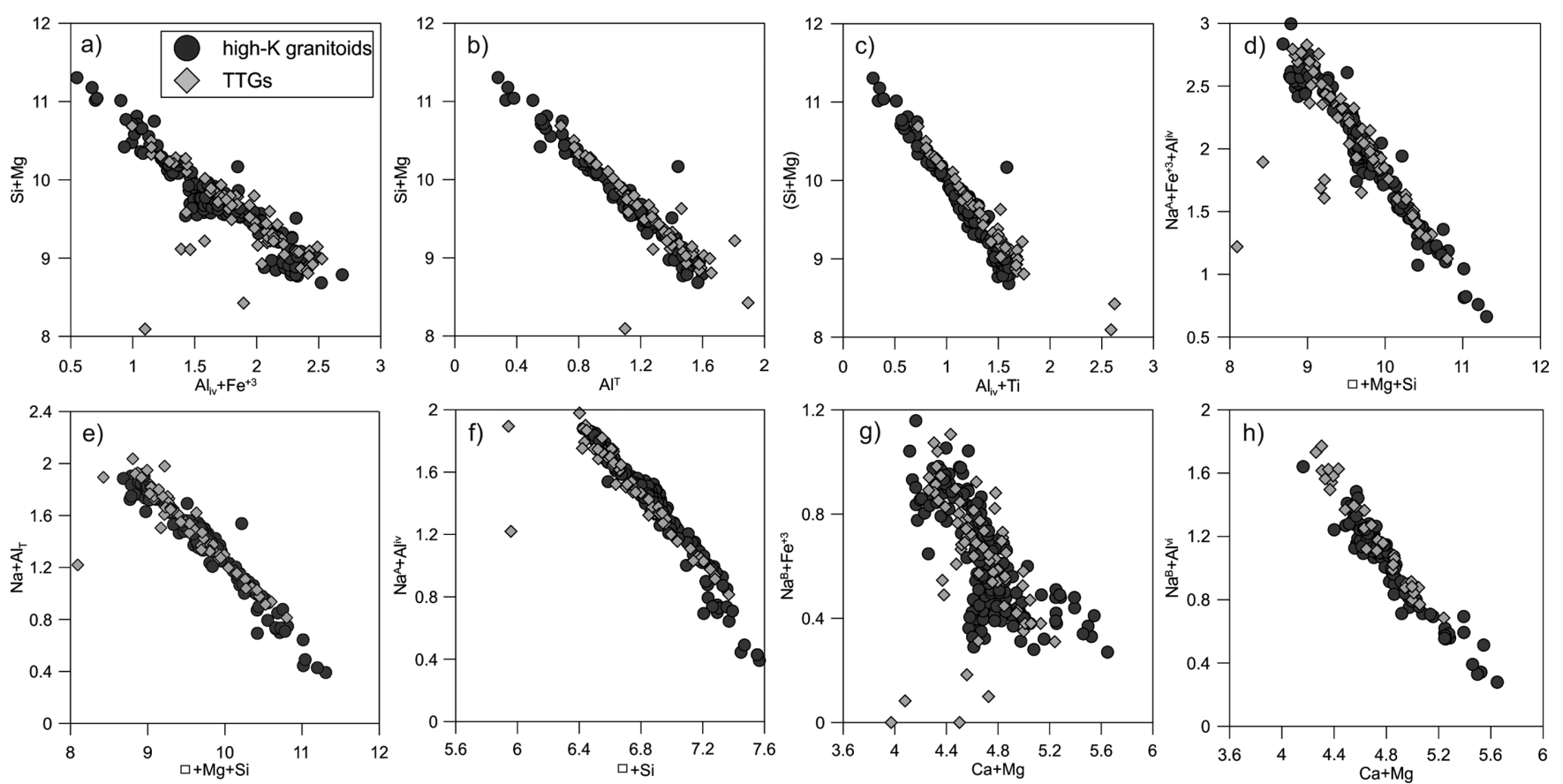

Figure 17. a-h) Plots illustrating various substitution mechanisms in amphiboles from $B C$. Lower values $(<0.2)$ of $N a_{B}+A l_{v i}$ are not shown in the plot (h). For references please see associated text.

\section{Magma Evolution}

Many factors could contribute to the diversity of the granites including the variability of the source rock undergoing partial melting, the nature and amount of residual minerals, degree of partial melting, varying anatectic conditions, stages of magmatic differentiation and extent of fractional crystallization (Joshi et al., 2014; Ray et al., 2015). It is not within the scope of the present study to evaluate the effects of these factors but the highly regular and limited nature of exchange vectors in amphiboles suggest only limiting the effect of these factors.

The plutonic magmatic rocks in the $\mathrm{BC}$ represent archives of the evolutionary history of magma generation, and the accretion of the continental crust, spanning over Paleo- to Meso- to Neo-Archaean. Though several episodes of crustal accretion are proposed, it is generally postulated that TTGs are dominant in Paleo- to Mesoarchaean, while during Neoarchaean, LSHM (hybrid granites) high-K granitoids were largely emplaced despite few local occurrences of Neoarchaean TTGs.

Two remarkable features emerging from the amphibole plots (Fig. 7, 15-17) are: firstly, there is a linear relation in the variation between amphiboles of TTGs and LSHM (hybrid granites) high-K granitoids, and secondly, the two granitoid varieties exhibit compositional overlapping and similarity in their amphibole chemistry. The linearity of the compositional pattern of the studied amphiboles suggests that the minor slope change at the tailing of the plot may be due to the effect of diffusion-driven substitution during the late metamorphism. By filtering out the late metamorphic effect, the observed compositional similarity and linearity are quite striking given that the TTGs and the (hybrid granites) high-K granitoid varieties have a significant age difference of the order of several hundred million years (Joshi et al., 2017).

The petrologic evolution in amphiboles can be explained by studying zoned crystals formed during magmatism or metamorphism. For instance, Howie and Zussman (1997) pointed out that the crystal changes during its growth in response to the changes in temperature, pressure, and chemical composition of fluids in the magmatic/metamorphic environment. It is known that the change in $\mathrm{Al}$ contents of hornblende with increasing pressure is governed by aluminium tschermakite substitution, while edenite and Ti-tschermakite substitution is temperature dependant (Blundy and Holland, 1990; Bachmann and Dungan, 2002). Accordingly, it is noticed that the amphiboles from the $B C$ preserve the signatures of both pressure (Al-Tschermack) (Fig. 17b) and temperature (Ti-Tschermak+edenite) (Fig. 17c,f) dependant substitutions. Thus, the rim to rim profiles of the studied amphiboles can be considered as a proxy for the evolution of the magma chamber. The $\mathrm{Al}_{\mathrm{T}}$ and $(\mathrm{Na}+\mathrm{K})_{\mathrm{A}}$ in the studied amphibole grains (Fig. 11-12) of high $-\mathrm{K}$ granitoids increase towards the rim, this suggests a near isobaric progressive heating of the high-K granitoid magma shortly before emplacement. A similar evolution was suggested for zoned amphiboles from Fish Canyon Magma by Bachman and Dungan (2002). To sum up, the temperature and pressure-induced zoning in the studied amphibole lead to crystallisation in an evolved magma with gradually changing pressure and temperature.

Compared to an earlier pressure and temperature estimate of 4.9$6.8 \mathrm{kbar}$ and $\sim 760^{\circ} \mathrm{C}$ from hornblende-plagioclase geothermobarometer (Chauhan et al., 2017), in this study, we observe a lower value $(4.10 \pm 0.20 \mathrm{kbar}$; Table 4$)$ for the calculated pressure of TTGs, while our estimated temperatures $\left(760 \pm 2{ }^{\circ} \mathrm{C}\right)$ is comparatively similar. In case of the two rock types studied here, the pressure of LSHM (hybrid granites) high-K granitoids (3.06 $\pm 0.40 \mathrm{kbar}$; Table 4$)$ is lower than those calculated for the TTGs $(4.10 \pm 0.20 \mathrm{kbar}$; Table 4$)$. On the other hand, the temperature estimate for TTGs is $(760 \pm 2)^{\circ} \mathrm{C}$ and that for LSHM (hybrid granites) high-K granitoids is $(745 \pm 12)^{\circ} \mathrm{C}$, which can be considered as more or less similar for both the rock types. Here we note 
that the observed limited variation in temperature for TTGs and a wide variation of the same in case of LSHM (hybrid granites) high-K granitoids corroborates well with the nature of $\mathrm{Al}$ zoning patterns in amphiboles. Finally, the overall composition of the studied amphiboles and the estimated temperature, fit well within the acceptable range of P-sensitivity of $\mathrm{Al}$ in amphibole barometer (Erdman et al., 2014). Consequently, we could infer a $\sim 4 \mathrm{~km}$ difference at the emplacement depths of the TTGs and LSHM (hybrid granites) high-K granitoids.

\section{Tectonic Scenario}

It is commonly believed that TTGs are formed from the partial melting of hydrous basalt; which can happen either in a subducting slab or in an overthickened mafic crust (Arth and Hanson, 1972; Jahn et al., 1981; Martin, 1986, 1994; Laurie and Stevens, 2012; Nagel et al., 2012; Hoffman et al., 2011). TTGs with the variable REE patterns (HREE enriched to HREE depleted) have been reported from the BC (Kaur et al., 2016; Joshi et al., 2017; Nasipuri et al., 2019). The variability of TTGs in the $\mathrm{BC}$ has been explained by melting of hydrated mafic rocks at variable depths: abundant garnet and rutile (deep), or garnet free (shallow) (Kaur et al., 2014; Joshi et al., 2017). Kaur et al. (2014) concluded that the older $(\sim 3.5 \mathrm{Ga})$ TTGs were formed by partial melting of pure oceanic crust, while the generation of younger TTGs happened by moderate to high degree of partial melting of the enriched mantle, at variable depths and with some assimilation from the pre-existing crust. Ram Mohan et al. (2012) also suggested a multistage process in supra-subduction zone regime, where slab dehydration led to release of water at low pressure and shallow depth, probably in the lower part of the thickened mafic crust. Recently based on bulk-rock geochemistry, anhydrous melting of pre-existing TTGs or mafic crust was suggested for the formation of high-K granitoids (Chauhan et al., 2017; Joshi et al., 2017). Chauhan et al. (2017) further suggested the development of a continental collisional tectonic regime in the Archaean-Paleoproterozoic. Additionally, it is also very important to consider the role of $\mathrm{H}_{2} \mathrm{O} / \mathrm{K}_{2} \mathrm{O}$ in the melt; because, the experiment of (Carrington and Watt, 1995) suggest that $\mathrm{H}_{2} \mathrm{O} / \mathrm{K}_{2} \mathrm{O}$ controls whether $\mathrm{K}$-feldspar will be a product or a reactant during water undersaturated dehydration melting, that lead to the enrichment of $\mathrm{K}$ in the melt. Considering all of the abovementioned factors, we infer that during Mesoarchaean and Paleoarchaean, TTGs with low-K content (at elevated $\mathrm{H}_{2} \mathrm{O} / \mathrm{K}_{2} \mathrm{O}$ ) formed by partial melting of hydrous basalt in over thickened mafic crust, which in turn assisted evolution of K-rich melt leading to the formation of late Neoarchaean high-K granitoids. In this context, two types of geodynamic situations can be envisaged in which the lower crustal melting occurs in a subduction setting. First, an elevated $\mathrm{H}_{2} \mathrm{O} / \mathrm{K}_{2} \mathrm{O}$ induces the melt of suitable composition to form TTGs, whereas, in the second situation, melting occurs in an under-saturated $\mathrm{H}_{2} \mathrm{O}$ environment. Moreover, the inferred possibility of elevated $\mathrm{H}_{2} \mathrm{O} / \mathrm{K}_{2} \mathrm{O}$ for the younger TTG type melt generation in $\mathrm{BC}$ is also substantiated by the occurrence of Neoarchaean high $\mathrm{P}$ metamorphic assemblage reported by Saha et al. (2011) from BC.

To summarise our discussion, the present study on amphibole compositions of the lower crustal rocks reveals that the crystallization of TTGs and High-K granitoids occurred under varying $\mathrm{P}_{\mathrm{H} 2 \mathrm{O}}$ conditions at variable depths.

\section{Conclusion}

The chemical composition of the minerals along with their textural occurrences in the magmatic rocks provides clues on physical and chemical conditions of the magma. In the present study, by using textural and mineral chemical compositions, we have worked towards understanding the evolution of TTGs and high-K hybrid granitoids from the Bundelkhand craton, India.

Firstly, we find that the plagioclase analysed from both the rock types shows variable content of anorthite, $\mathrm{An}_{1}$ to $\mathrm{An}_{31}$, which conforms with multiple magmatic pulses. Secondly, the studied biotite demonstrates compositional similarity to those previously reported from calc-alkaline plutons. The biotite composition varies from $\mathrm{Mg}$ to Fe rich. Precisely, biotite in Paleoarchaean TTGs and Neoarchaean LSHM (hybrid) high-K granitoids are Mg-rich, whereas, those in Neoarchaean TTGs are rich in Fe. Therefore, the observed compositional variation of biotite suggests that the crystallisation conditions of magma changed during Archaean: the oxidising conditions largely prevailed during both Paleoarchaean and ArchaeanProterozoic transition period; shortly interrupted by reducing condition during the beginning of Neoarchaean. Thirdly, our study reveals that the amphibole both from TTGs and high-K granitoids (hybrid granites) are magmatic, zoned, and calcic. In particular, the studied amphibole is characterised by thepresence of magnesiohornblende and infrequent occurrence of tschermakite, magnesiohastingsite, and edenite compositions. The variation in amphibole compositions in terms of exchange vectors show well defined linear trends indicating melt control over crystallisation and evolution of amphibole chemistry. In addition to the mineral chemistry study, finally, the geotherobarometric analysis of the studied granitoids indicates a pressure around $4 \mathrm{kbar}$ at $\sim 760^{\circ} \mathrm{C}$ for TTG formation, which is higher compared to a pressure of around $3 \mathrm{kbar}$ at $\sim 750{ }^{\circ} \mathrm{C}$ for LSHM high-K granitoids (hybrid granites). Such a feature might have been caused due to the difference in depth of emplacements of the two different rock types.

To conclude we propose that, during the Paleo to Mesoarchaean, TTGs with low-K content were formed by partial melting of hydrous basalt at elevated $\mathrm{H}_{2} \mathrm{O} / \mathrm{K}_{2} \mathrm{O}$ condition in the over-thickened mafic crust. This assisted evolution of K-rich melt leading to the formation of late Neoarchaean high-K granitoids. Therefore, it is plausible that the crystallisation of TTGs and High-K granitoids in the Bundelkhand Craton, India, occurred from the melting of lower crustal rocks under varying $\mathrm{P}_{\mathrm{H} 2 \mathrm{O}}$ conditions at different depths of emplacement.

\section{Acknowledgement}

KBJ, NS, VN, JKT, thank Secretary, MoES, Govt of India and Director, NCESS for providing funds and unconditional support to carry out the work. NS also thank Prof. Somnath Dasgupta for the discussions that helped improving the manuscript. KBJ and NS acknowledge support from Eldose in thin section lab at NCESS, Prof. B. Mishra and Saptarshi from IIT, Kharagpur for proving EPMA facility. 


\section{References}

Abdel-Rahman A. 1994, Nature of Biotite from Alkaline, Calc-alkaline, and Peraluminous Magmas. Journal of Petrology, v. 35, pp. 525-41.

Alfimova, N., Raza, M.B., Felitsyn, S., Matrenichev, V., Bogomolov, E., Nasipuri, P., Saha, L., Pati, J.K. and Kumar, V., 2019, Isotopic Sm-Nd signatures of Precambrian Banded Iron Formation from the Fennoscandian shield, East-European Platform, and Bundelkhand craton, India. Precambrian Research, v. 328, pp. 1-8.

Anderson, J.L., Barth, A.P., Wooden, J.L. and Mazdab, F., 2008, Thermometers and thermobarometers in granitic systems. Reviews in Mineralogy and Geochemistry, v. 69, pp. 121-142.

Anderson, J.L., and Smith, D.R., 1995, The effects of temperature and $\mathrm{fO}_{2}$ on the Al-in-hornblende barometer. American Mineralogist, v. 80, pp. 549-559.

Arth, J.G., and Hanson, G.N., 1972, Quartz diorites derived by partial melting of eclogites or amphibolite at mantle depths. Contributions to Mineralogy and Petrology, v. 37, pp. 161-174.

Bachmann, O., and Dungan, M.A., 2002, Temperature-induced Al-zoning in hornblendes of the Fish Canyon magma, Colorado. American Mineralogist, v. 87, pp. 1062-1076.

Basu, A.K., 1986, Geology of Bundelkhand granite massif, Central India. Records Geological Survey of India. v. 101, pp. 61-124.

Blundy, J.D., and Holland, T.J., 1990, Calcic amphibole equilibria and a new amphibole-plagioclase geothermometer. Contributions to Mineralogy and Petrology, v. 104, pp. 208-224.

Bucholz, C.E., Jagoutz, O., Schmidt, M.W., and Sambuu, O., 2014, Fractional crystallization of high-K arc magmas: biotite-versus amphiboledominated fractionation series in the Dariv Igneous complex, Western Mongolia. Contributions to Mineralogy and Petrology, v. 168, p. 1072.

Campos, T., Neiva, A.M., Nardi, L.V.S., Pereira, L.S., Bonzanini, L.F., Petta, R. and Meyer, F.M., 2005, Magmatic epidote and amphibole from the Rio Espinharas hybrid complex, northeastern Brazil. Pesquisas em Geociências, v. 32, pp. 41-55.

Carrington, D.P., and Watt, G.R., 1995, A geochemical and experimental study of the role of K-feldspar during water-undersaturated melting of metapelites. Chemical Geology, v. 122, pp. 59-76.

Champion, D.C., and Sheraton, J.W., 1997, Geochemistry and Nd isotope systematics of Archaean granites of the Eastern Goldfields, Yilgarn Craton, Australia: implications for crustal growth processes. Precambrian Research, v. 83, pp. 109-132.

Chauhan, H., Saikia, A., and Ahmad, T., 2017, Episodic crustal growth in the Bundelkhand craton of central India shield: Constraints from petrogenesis of the tonalite-trondhjemite-granodiorite gneisses and K-rich granites of Bundelkhand tectonic zone. Journal of Earth System Science, v. 127 , p. 44.

Condie, K.C., 1993, Chemical composition and evolution of the upper continental crust: contrasting results from surface samples and shales. Chemical geology, v. 104, pp. 1-37.

Condie, K.C., and O'Neill, C., 2010, The Archean-Proterozoic boundary: $500 \mathrm{My}$ of tectonic transition in Earth history. American Journal of Science, v. 310, pp. 775-790.

Dey, S., Pandey, U.K., Rai, A.K., and Chaki, A., 2012, Geochemical and $\mathrm{Nd}$ isotope constraints on petrogenesis of granitoids from NW part of the eastern Dharwar craton: possible implications for late Archaean crustal accretion. Journal of Asian Earth Sciences, v.45, pp. 40-56.

Dhuime, B., Hawkesworth, C.J., Storey, C.D., and Cawood, P.A., 2011, From sediments to their source rocks: $\mathrm{Hf}$ and $\mathrm{Nd}$ isotopes in recent river sediments. Geology, v. 39, pp. 407-410.

Dhuime, B., Wuestefeld, A., and Hawkesworth, C.J., 2015, Emergence of modern continental crust about 3 billion years ago. Nature Geoscience, v. 8, pp. 552-555.

Erdmann, S., Martel, C., Pichavant, M., and Kushnir, A., 2014, Amphibole as an archivist of magmatic crystallization conditions: problems, potential, and implications for inferring magma storage prior to the paroxysmal 2010 eruption of Mount Merapi, Indonesia. Contributions to Mineralogy and Petrology, v. 167, p. 1016.

Foster, M.D., 1960. Interpretation of the composition of lithium micas. U, S. Geol. Suru. Prof. Pap. 354-E, El15-8147.

Frost, C.D., Frost, B.R., Chamberlain, K.R., and Hulsebosch, T.P., 1998, The Late Archean history of the Wyoming province as recorded by granitic magmatism in the Wind River Range, Wyoming. Precambrian Research, v. 89, pp. 145-173.

Frost, C.D., Frost, B.R., Kirkwood, R., and Chamberlain, K.R., 2006, The tonalite-trondhjemite-granodiorite (TTG) to granodiorite-granite (GG) transition in the late Archean plutonic rocks of the central Wyoming Province. Canadian Journal of Earth Sciences, v. 43, pp. 1419-1444.

Gilbert, M.C., Helz, R.T., Popp, R.K., Spear, F.S., 1982. Experimental studies of amphibole stability. Reviews in Mineralogy and Geochemistry, v. 9B, pp. 229-353.

Grove, T.L., Elkins-Tanton, L.T., Parman, S.W., Chatterjee, N., Müntener, O., and Gaetani, G.A., 2003, Fractional crystallization and mantle-melting controls on calc-alkaline differentiation trends. Contributions to Mineralogy and Petrology, v. 145, pp. 515-533.

Halla, J., 2018, Highlights on geochemical changes in Archaean granitoids and their implications for early earth geodynamics. Geosciences, v. 8 , p. 353.

Halla, J., van Hunen, J., Heilimo, E., and Hölttä, P., 2009, Geochemical and numerical constraints on Neoarchean plate tectonics. Precambrian Research, v. 174, pp. 155-162.

Hammarstrom, J.M., and Zen, E.A., 1986, Aluminum in hornblende: an empirical igneous geobarometer. American Mineralogist, v. 71, pp. 1297-1313.

Hawkesworth, C.J., Cawood, P.A., Dhuime, and B., Kemp, T.I.S., 2017, Earth's continental lithosphere through time. Annual Review of Earth and Planetary Sciences, v. 45, pp. 169-198.

Hawkesworth, C.J., Dhuime, B., Pietranik, A.B., Cawood, P.A., Kemp, and A.I.S., Storey, C.D., 2010, The generation and evolution of the continental crust. Journal of Geological Society of London, v. 167, pp. 229-248.

Hoffmann, J.E., Münker, C., Næraa, T., Rosing, M.T., Herwartz, D., GarbeSchönberg, D., and Svahnberg, H., 2011, Mechanisms of Archean crust formation inferred from high-precision HFSE systematics in TTGs. Geochimica et Cosmochimica Acta, v. 75, pp. 4157-4178.

Holland, T., and Blundy, J., 1994, Non-ideal interactions in calcic amphiboles and their bearing on amphibole-plagioclase thermometry. Contributions to Mineralogy and Petrology, v. 116, pp. 433-447.

Hollister, L.S., Grissom, G.C., Peters, E.K., Stowell, H.H., and Sisson, V.B., 1987, Confirmation of the empirical correlation of $\mathrm{Al}$ in hornblende with pressure of solidification of calc-alkaline plutons. American Mineralogist, v. 72, pp. 231-239.

Hölttä, P., Heilimo, E., Huhma, H., Kontinen, A., Mertanen, S., Mikkola, P., Paavola, J., Peltonen, P., Semprich, J., Slabunov, A. and SorjonenWard, P., 2014,The Archaean Karelia and Belomorian Provinces, Fennoscandian Shield. In Evolution of Archean crust and early life (pp. 55-102). Springer, Dordrecht

Howie, R.A. and Zussman, J., 1997, Rock-forming minerals (Vol. 3). Geological Society of America.

Jagoutz, O., Schmidt, M.W., Enggist, A., Burg, J.P., Hamid, D., and Hussain, S., 2013, TTG-type plutonic rocks formed in a modern arc batholith by hydrous fractionation in the lower arc crust. Contributions to Mineralogy and Petrology, v. 166, pp. 1099-1118.

Jahn, B.M., Glikson, A.Y., Peucat, J.J., and Hickman, A.H., 1981, REE geochemistry and isotopic data of Archean silicic volcanics and granitoids from the Pilbara Block, Western Australia: implications for the early crustal evolution. Geochimica et Cosmochimica Acta, v. 45, pp. $1633-1652$.

Jayananda, M., Dey, S., and Aadhiseshan, K.R., 2020, Evolving Early Earth: Insights from Peninsular India. Geodynamics of the Indian Plate. 
Springer, Cham, pp. 5-103.

Johnson, M.C., and Rutherford, M.J., 1989, Experimental calibration of the aluminum-in-hornblende geobarometer with application to Long Valley caldera (California) volcanic rocks. Geology, v. 17, pp. 837841

Joshi, K. B., and Slabunov, A.I., 2019, Neoarchean sanukitoids from the Karelian and Bundelkhand cratons: comparison of composition, regional distribution and geodynamic setting. Transactions of Karelian Research Centre of Russian Academy of Sciences, v. 2, pp. 1-21.

Joshi, K.B., Bhattacharjee, J., Rai, G., Halla, J., Ahmad, T., Kurhila, M., Heilimo, E., and Choudhary, A.K., 2017, The diversification of granitoids and plate tectonic implications at the Archaean-Proterozoic boundary in the Bundelkhand Craton, Central India. Geological Society, London, Special Publications, 449, pp. 123-157.

Joshi, K.B., Ray, S., Joshi, D., and Ahmad, T., 2014, Geochemistry of pegmatites from South Delhi Fold Belt: a case study from Rajgarh, Ajmer district, Rajasthan. Current Science, v. 106, pp. 1725-1730.

Kaur, P., Zeh, A., Chaudhri, N., and Eliyas, N., 2016, Unravelling the record of Archaean crustal evolution of the Bundelkhand Craton, northern India using $\mathrm{U}-\mathrm{Pb}$ zircon-monazite ages, $\mathrm{Lu}-\mathrm{Hf}$ isotope systematics, and whole-rock geochemistry of granitoids. Precambrian Research, v. 281, pp. 384-413.

Kaur, P., Zeh, A., and Chaudhri, N., 2014, Characterisation and U-Pb-Hf isotope record of the 3.55 Ga felsic crust from the Bundelkhand Craton, northern India. Precambr. Research, v. 255, pp. 236-244.

Kostyuk, E.A., and Sobolev, V.S., 1969, Paragenetic types of calciferous amphiboles of metamorphic rocks. Lithos, v. 2, pp. 67-81.

Kretz, R., 1983, Symbols for rock-forming minerals: American Mineralogist, v. 68, pp. 277-279.

Lalonde, A. E., and Bernard, P., 1993, Composition and Color of Biotite from Granites: Two Useful Properties in the Characterization of Plutonic Suites from the Hepburn Internal Zone of Wopmay Orogen, Northwest Territories. Canadian Mineralogists. v. 31, pp. 203-217.

Laurent, O., Rapopo, M., Stevens, G., Moyen, J.F., Martin, H., Doucelance, R., and Bosq, C., 2014, Contrasting petrogenesis of $\mathrm{Mg}-\mathrm{K}$ and $\mathrm{Fe}-\mathrm{K}$ granitoids and implications for post-collisional magmatism: case study from the Late-Archean Matok pluton (Pietersburg block, South Africa). Lithos, v. 196, pp. 131-149.

Leake, B.E., 1965, The relationship between composition of calciferous amphibole and grade of metamorphism. Controls of metamorphism, v. 11965 , p. 2997318.

Leake, B.E., Woolley, A.R., Arps, C.E., Birch, W.D., Gilbert, M.C., Grice, J.D., Hawthorne, F.C., Kato, A., Kisch, H.J., Krivovichev, V.G., and Linthout, K., 1997, Report. Nomenclature of amphiboles: report of the subcommittee on amphiboles of the international mineralogical association commission on new minerals and mineral names. Mineralogical. Magazine, v. 61, pp. 295-321

Leake, B.E., Woolley, A.R., Birch, W.D., Burke, E.A., Ferraris, G., Grice, J.D., Hawthorne, F.C., Kisch, H.J., Krivovichev, V.G., Schumacher, J.C., and Stephenson, N.C., 2004, Nomenclature of amphiboles: additions and revisions to the International Mineralogical Association's amphibole nomenclature. Mineralogical. Magazine, v. 68, pp. 209-215.

Lee, C.T.A., Morton, D.M., Kistler, R.W., and Baird, A.K., 2007, Petrology and tectonics of Phanerozoic continent formation: From island arcs to accretion and continental arc magmatism. Earth and Planetary Science Letters, v. 263, pp. 370-387.

Lowe, D.R., and Tice, M.M., 2007, Tectonic controls on atmospheric, climatic, and biological evolution 3.5-2.4 Ga. Precambrian Research, v. 158, pp. 177-197.

Malviya, V.P., Arima, M., Pati, J.K., and Kaneko, Y., 2006, Petrology and geochemistry of metamorphosed basaltic pillow lava and basaltic komatiite in the Mauranipur area: subduction related volcanism in the Archean Bundelkhand craton, Central India. Journal of Mineralogical and Petrological Sciences, v. 101, pp. 199-217.

Manglik, A., Adilakshmi, L., Suresh, M., and Thiagarajan, S., 2015, Thick sedimentary sequence around Bahraich in the northern part of the central Ganga foreland basin. Tectonophysics, v. 653, pp.33-40.

Martin, H., 1994, The Archean grey gneisses and the genesis of continental crust. In: Condie, K.C. (Ed.), Archean Crustal Evolution. Developments in Precambrian geology. Elsevier, Amsterdam, pp. 205-259.

Martin, H., Moyen, J.F., and Rapp, R., 2010, The sanukitoid series: magmatism at the Archaean-Proterozoic transition. Earth and Environmental Science Transactions of the Royal Society of Edinburgh, v. 100, pp. 15-33.

Masoudi, F. and Jamshidi-Badr, M., 2008, Biotite and hornblende composition used to investigate the nature and thermobarometry of Pichagchi Pluton, Northwest Sanandaj-Sirjan Metamorphic Belt, Iran. Journal of Science Islamic Republic of Iran. v. 19, pp. 329-38.

Mikkola, P., Lauri, L.S., and Käpyaho, A., 2012, Neoarchean leucogranitoids of the Kianta Complex, Karelian Province, Finland: source characteristics and processes responsible for the observed heterogeneity. Precambrian Research. v. 206, pp. 72-86.

Mondal, M.E.A., Goswami, J.N., Deomurari, M.P., and Sharma, K.K., 2002, Ion microprobe ${ }^{207} \mathrm{~Pb} /{ }^{206} \mathrm{~Pb}$ ages of zircons from the Bundelkhand massif, northern India: implications for crustal evolution of the Bundelkhand-Aravalli protocontinent. Precambrian Research, v. 117, pp. 85-100.

Mondal, M.E.A., Sharma, K.K., Rahman, and A., Goswami, J.N., 1998, Ion microprobe ${ }^{207} \mathrm{~Pb} /{ }^{206} \mathrm{~Pb}$ zircon ages for gneiss-granitoid rocks from Bundelkhand massif: Evidence for Archaean components. Current Science, v. 74, pp. 70-75.

Mondal, M.E.A., and Zainuddin, S.M., 1997, Geochemical characteristics of the granites of Bundelkhand massif, central India. Journal of Geological Society of India, v. 50, pp. 69-74.

Moyen, J.F., Martin, H., Jayananda, M., and Auvray, B., 2003, Late Archaean granites: a typology based on the Dharwar Craton (India). Precambrian Research, v. 127, pp. 103-123.

Moyen, J.F., 2019, Archean granitoids: classification, petrology, geochemistry and origin. Geological Society, London, Special Publications, v. 489.

Moyen, J.F., Martin, H., and Jayananda, M., 2001, Multi-element geochemical modelling of crust-mantle interactions during late-Archaean crustal growth: the Closepet granite (South India). Precambrian Research, v. 112, pp. 87-105.

Moyes, A.B., 1991, Variation in amphibole composition from the Andean Intrusive Suite across the Antarctic Peninsula. In: Thomson, M.R.A.; Crame, J.A.; Thomson, J.W., (eds.) Geological evolution of Antarctica. Proceedings of the Fifth International Symposium on Antarctic Earth Sciences, Cambridge, August 1987.Cambridge, Cambridge University Press, 375-379 pp.

Nagel, T.J., Hoffmann, J.E., and Münker, C., 2012, Generation of Eoarchean tonalite-trondhjemite-granodiorite series from thickened mafic arc crust. Geology, v. 40, pp. 375-378.

Nasipuri, P., Saha, L., Hangqiang, X., Pati, J.K., Satyanarayanan, M., Sarkar, S., Bhandari, A., and Gaur, Y., 2019, Paleoarchean Crustal Evolution of the Bundelkhand Craton, North Central India Chapter Outline. Earth's Oldest Rocks, pp. 793-817. doi.org/10.1016/B978-0444-63901-1.00031-9.

Palin, R.M., White, R.W., and Green, E.C., 2016, Partial melting of metabasic rocks and the generation of tonalitic-trondhjemitic-granodioritic (TTG) crust in the Archaean: Constraints from phase equilibrium modelling. Precambrian Research, v. 287, pp. 73-90.

Pati, J.K., Patel, S.C., Pruseth, K.L., Malviya, V.P., Arima, M., Raju, S., Pati, P., and Prakash, K., 2007, Geology and geochemistry of giant quartz veins from the Bundelkhand Craton, central India and their implications. Journal of Earth System Science, v. 116, p. 497.

Pati, J.K., Raju, S., Mamgain, V.D., and Shankar, R., 1997, Record of gold mineralization in parts of Bundelkhand Granitoid Complex (BGC). Journal of the Geological Society of India, v. 50, pp. 601-606.

Pradhan, V.R., Meert, J.G., Pandit, M.K., Kamenov, G., and Mondal, M.E.A., 2012, Paleomagnetic and geochronological studies of the mafic dyke 
swarms of Bundelkhand craton, central India: implications for the tectonic evolution and paleogeographic reconstructions. Precambrian Research, v. 198-199, pp. 51-76.

Putirka, K., 2016, Amphibole thermometers and barometers for igneous systems and some implications for eruption mechanisms of felsic magmas at arc volcanoes. American Mineralogist, v. 101, pp. 841-858.

Radhakrishna, B.P., 1989, Suspected Tectono-stratigraphic terrane elements in the Indian subcontinent. Journal of the Geological Society of India, v. 34, pp. 1-24.

Ram Mohan, M., Singh, S.P., Santosh, M., Siddiqui, M.A., and Balaram, V., 2012, TTG suit from the Bundelkhand Craton, Central India: Geochemistry, petrogenesis and implications for Archean crustal evolution. Journal of Asian Earth Science, v. 58, pp. 38-50.

Rao, J.M., Rao, G.V.S.P., Widdowson, M., and Kelley, S.P., 2005, Evolution of Proterozoic mafic dyke swarms of the Bundelkhand Granite Massif, Central India. Current Science, v. 88, pp. 502-506.

Ray, S., Joshi, K.B., Sundarraman, S., Joshi, D., and Ahmad, T., 2015, Geochemical and Petrogenetic Study of Proterozoic Sewariya and Govindgarh Granitoids from South Delhi Fold Belt. Current Science, v. 109 , pp. $1458-1465$.

Ridolfi, F., and Renzulli, A., 2012, Calcic amphiboles in calc-alkaline and alkaline magmas: thermobarometric and chemometric empirical equations valid up to $1,130{ }^{\circ} \mathrm{C}$ and $2.2 \mathrm{GPa}$. Contributions to Mineralogy and Petrology, v. 163, pp.877-895.

Rosas, J.C., and Korenaga, J., 2018, Rapid crustal growth and efficient crustal recycling in the early Earth: Implications for Hadean and Archean geodynamics. Earth and Planetary Science Letters, v. 494, pp. 42-49.

Saha, L., Frei, D., Gerdes, A., Pati, J.K., Sarkar, S., Patole, V., Bhandari, A., and Nasipuri, P., 2016, Crustal geodynamics from the Archaean Bundelkhand Craton, India: constraints from zircon $\mathrm{U}-\mathrm{Pb}-\mathrm{Hf}$ isotope studies. Geological Magazine, v. 153, pp. 179-192.

Saha, L., Pant, N.C., Pati, J.K., Upadhaya, D., Berndt, J., Bhattacharya, A., and Satyanarayan, M., 2011, Neoarchean high pressure margaritephengitic muscovite-chlorite corona mantled corundum in quartz-free high-Mg,Al phlogopite-chlorite schists from the Bundelkhand craton, north-central India. Contributionns to Mineralogy and Petrology, v. 161 , pp. 511-530.

Sawyer, E.W., 1998, Formation and evolution of granite magmas during crustal reworking: the significance of diatexites. Journal of Petrology, v. 39 , pp. $1147-1167$.

Schmidt, M.W., 1992, Amphibole composition in tonalite as a function of pressure: an experimental calibration of the Al-in-hornblende barometer. Contributions to Mineralogy and Petrology, v. 110, pp. 304-310.

Shabani, A.T., and Lalonde, A., 2003, Composition of biotite from granitic rocks of the Canadian Appalachian: A potential tectonomagmatic indicator? Canadian Mineralogist, v. 41, pp. 1381-1396.

Singh, V.K., Verma, S.K., Singh, P.K., Slabunov, A.I., Mishra, S., and Chaudhary, N., 2019, Archean crustal evolution of the Bundelkhand Craton: Evidence from granitoid magmatism. Geological Society, London, Special Publications, p. 489, doi:10.1144/sp489-2018-72

Singh, V.K., and Slabunov, A., 2016, Two types of Archaean supracrustal belts in the Bundelkhand craton, India: geology, geochemistry, age and implication for craton crustal evolution. Journal of the Geological Society of India, v. 88, pp. 539-548.

Singh, P.K., Verma, S.K., Singh, V.K., Moreno, J.A., Oliveira, E.P., and Mehta, P., 2018, Geochemistry and petrogenesis of sanukitoids and
high-K anatectic granites fromthe Bundelkhand Craton, India: Implications for late-Archean crustal evolution. Journal of Asian Earth Sciences, v. 174, pp. 263-282.

Slabunov, A.I., and Singh, V.K., 2018, Meso-Neoarchaean crustal evolution of the Bundelkhand Craton, Indian Shield: new data from greenstone belts. International Geology Review, v. 61, pp. 1409-1428.

Slabunov, A., Singh, V.K., Joshi, K.B., and Li, X., 2017a, Paleoarchean zircons from quartzite of South Bundelkhand Supracrustal Complex: origin and implications for crustal evolution in Bundelkhand Craton, Central India. Current Science, v. 112, p. 794.

Slabunov, A.I., Singh, V.K., Shchiptsov, V.V., Lepekhina, E.N., and Kevlich, V.I., 2017b, A new Paleoproterozoic 1.9-1.8 Ga event in the crustal evolution of the Bundelkhand Craton, India: the results of SHRIMP Dating of zircons from giant quartz veins. In: Slabunov, A.I., Svetov, S.A., Baltibaev, Sh.K. (Eds.), Early Precambrian vs Modern Geodynamics. Extended Abstracts and Field Trips Guide. Petrozavodsk: KarRC RAS, pp. 239-241.

Smithies, R.H., and Champion, D.C., 2000, The Archaean high-Mg diorite suite: links to tonalite-trondhjemite-granodiorite magmatism and implications for early Archaean crustal growth. Journal of Petrology, v. 41, pp. $1653-1671$.

Smith, J.S., Brown, and W.L., 1988, Feldspar Minerals, Vol. 1, SpringerVerlag, Berlin, Heidelberg, pp. 298-390.

Sorcar, N., Joshi, K.B., Oliveira, E. P., Tomson, J.K., and Nandakumar, V. 2020, Characterization of partial melting event of garnet-cordierite gneiss from Kerala Khondalite Belt, India. Geoscience Frontiers, v. 11, pp. 597-611.

Stein, E., and Dietl, C., 2001, Hornblende thermobarometry of granitoids from the Central Odenwald (Germany) and their implications for the geotectonic development of the Odenwald. Mineralogy and Petrology, v. 72 , pp. $185-207$.

Sylvester, P.J., 1994, Archaean granite plutons. In: Condie, K.C. (Ed.), The Archean Crustal Evolution, Developments in Precambrian Geology. Elsevier, Amsterdam, pp. 261-314.

Verma, S.K., Verma, S.P., Oliveira, E.P., Singh, V.K., and Moreno, J.A., 2016, LA-SF-ICP-MS zircon U-Pb geochronology of granitic rocks from the central Bundelkhand greenstone complex, Bundelkhand craton, India. Journal of Asian Earth Sciences, v. 118, pp. 125-137.

Vyhnal, C.R., McSween, H.Y., and Speer, J.A., 1991, Hornblende chemistry in southern Appalachian granitoids: implications for aluminium hornblende thermobarometry and magmatic epidote stability. American Mineralogist, v. 76, pp. 167-188.

Windley, B.F., 1984, The Archaean-Proterozoic boundary. Tectonophysics. v. 105, pp. 43-53.

Wones, D.R., and Eugster, H.P., 1965, Stability of Biotite: Experiment, Theory, and Application. American Mineralogists, v. 50, pp. 1228-1272.

Zen, E., 1988, Tectonic significance of high-pressure plutonic rocks in the western Cordillera of North America. In: Ernst WG (ed) Metamorphism and crustal evolution of the western United States. Prentice-Hall, Englewood Cliffs, pp 41-67 Rubey, VII.

Zhang, J., Humphreys, M.C., Cooper, G.F., Davidson, J.P., and Macpherson, C.G., 2017, Magma mush chemistry at subduction zones, revealed by new melt major element inversion from calcic amphiboles. American Mineralogist: Journal of Earth and Planetary Materials, v. 102, pp. 1353-1367. 


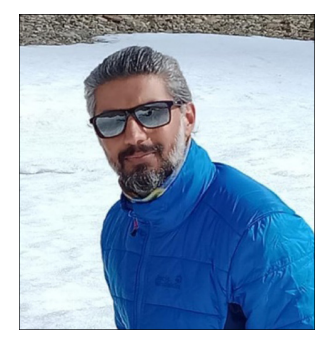

Kumar Batuk Joshi is currently working as a scientist at NCESS in Thiruvananthapuram, Kerala, India. He obtained his $\mathrm{PhD}$ from the University of Delhi on Archean crustal evolution in Bundelkhand Craton, India. Later, he worked as a Post-doctoral Fellow at Physical Research Laboratory (PRL), India and Young Scientist at Institute of Geology, Karelian Research Centre, Russian Academy of Science, Petrozavodsk, Russia. His current focus is on understanding Archaean Crustal evolution using isotope geochemistry and $\mathrm{U}-\mathrm{Pb} / \mathrm{Hf}$ isotopes in zircon.

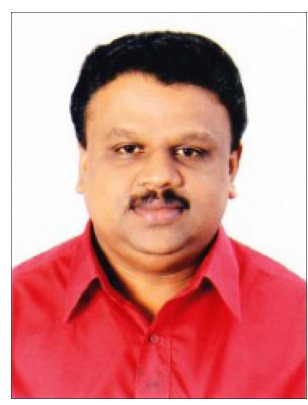

V. Nanda-Kumar is a Scientist in the National Centre for Earth Science Studies (NCESS) in Trivandrum, India. He obtained his Ph.D. degree from the Kerala University. Under the Royal Society - INSA programme (1998 and 2010) he carried out research at the University of Edinburgh, U.K. He has been the Principal Investigator of several projects funded by the World Bank, the Department of Science and Technology (DST) if India, the Ministry of Earth Sciences (MoES) of India, etc. His fields of interest include metamorphic petrology, geochronology and mobility of elements in melts. He has published several research papers and is a life member in many professional and academic societies including the Mineralogical Society of America, Geological Society of India, Indian Society of Remote Sensing and the Soil Conservation Society of India. Dr. Nandakumar has recently established a state-of-the-art Geo-Fluids Research Laboratory and a National Facility for Fluid Inclusion Research in NCESS. He has one patent to his credit.

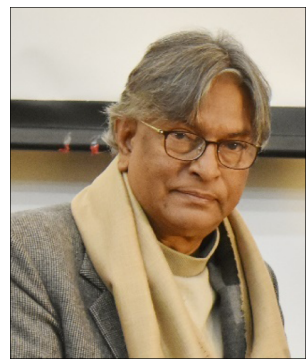

Talat Ahmad is Professor of Geology at the University of Delhi, presently Vice Chancellor at the University of Kashmir. Did Ph.D. from JNU, New Delhi 1985. PDF at Cambridge, UK, Leicester, UK \& Nagoya, Japan. Fellow of all three Science Academies of India: FNA, New Delhi, FASc, Bangaluru and FNASc, Allahabad \& J.C. Bose National Fellow. Received prestigious Awards as National Mineral Award, 1994, S.M. Naqvi Gold Medal 2013 and many others. Specialization: Geochemisty-Petrology and Himalayan Geology. Research interests: Precambrian magmatism and crustal evolution in the northern Indian Shield. Himalayan magmatism and geodynamic evolution of the Himalayan Mountain Belt.

J. K. Tomson is a Ph.D. in Geology from National Geophysical Research Institute, Hyderabad. Presently, he is a Scientist in Solid Earth Research Group in National Centre for Earth Science Studies, Thiruvananthapu$\mathrm{ram}$. His specialization is in petrology, geochemistry and isotope studies of granulite rocks of southern India. Currently, his research focuses on LA-ICPMS U-Pb dating and trace element characterization of accessory minerals and their importance in understanding terrain evolution. 